\title{
Needs Analysis on English for Vocational Purpose for Students of Hospitality Department
}

\section{Kaharuddin, Hikmawati, and Burhanuddin Arafah}

Universitas Islam Negeri (UIN) Alauddin Makassar, Universitas Negeri Makassar (UNM), Universitas Hasanuddin Makassar

\section{Abstract}

Needs analysis occupies a primary role in developing the curriculum, syllabus and the teaching materials of English for vocational purposes (EVP). This study aims to recognize the needs (linguistic, functions, learning preferences and problems of learning) of vocational English for the students of hospitality department. Development research method was used to carry out this study by involving 105 Hospitality students, 2 English teachers as well as 21 hospitality employees. Questionnaires were distributed to obtain data about the needs. The data were then analyzed by frequency, percentage, as well as mean scores. The findings indicated four primary needs inventory. The first,

Corresponding Author:

Kaharuddin

Andi.kaharuddin@uin-

alauddin.ac.id

Received: 1 July 2019

Accepted: 18 July 2019

Published: 31 July 2019

Publishing services provided by Knowledge E

(c) Kaharuddin et al. This article is distributed under the terms of the Creative Commons

Attribution License, which permits unrestricted use and redistribution provided that the original author and source are credited.

Selection and Peer-review unde the responsibility of the AICLL 2019 Conference Committee. speaking is dominantly selected as the most important skills to learn, then writing, reading and listening skills. The second, the most important language functions to learn in terms of vocational English for hospitality were Using telephone, giving and receiving guests, dealing guests' requests, describing hotel facilities, asking for repeats, responding to the guests' complain and offering help. The third, the most relevant learning preferences were warming up, games and work in pairs. The forth, problems of learning English included inability to use appropriate words and expressions, inadequate vocabulary, lack of grammar knowledge and insufficient knowledge of the topics. Based on the results achieved from this study, it can be proposed that revisions in the current English teaching materials for the students of hospitality department at Vocational high School 2 Pangkep seem to be necessary, to offer more reliable and effective EVP courses.

Keywords: English for Specific Purpose (ESP), English for Vocational Purpose (EVP), Needs Analysis (NA), Hospitality.

\section{Introduction}

In this globalization era, English is widely used as a lingua franca in many aspects of human life such as education, media and communication, diplomatic issues, business and services. Therefore, English is learnt globally by a large number of people in various sectors to meet their various needs of human communication (Bahar, K. 2014). 
the world. In Indonesia, English is presently recognized as the only foreign language included as a compulsory subject in schools which is taught for eight or nine years from primary schools to higher education (Yassi, A. H. \& Kaharuddin 2018). In addition, English is learnt in two different perspectives i.e. English is learnt from the perspective of general purpose also known as general English and English is learnt from the perspective of specific purpose also known as ESP. General English is commonly taught for mastering English for general communication skills. Besides, ESP is taught for mastering English for specific communication purpose such as English for engineers, doctors, lawyers, etc. (Kaharuddin, A and Latif, I, 2017, Kaharuddin, A. 2019).

In this regard, Hyland (2007) is of the opinion that the field of English for specific purposes (ESP), which addresses the communicative needs and practices of particular professional of occupational groups, has developed rapidly in the past forty years to become a major force in English language teaching and research. ESP draws its strength from an eclectic theoretical foundation and a commitment to research-based language education, which seeks to reveal the constraints of social context on language use and the ways learners can gain control over this (p. 391). By agreeing with these observations over ESP program, in this research paper, we tried to find out the needs for designing an ESP course for teachers with a close view on current constraints of social context of their teaching environment and professional trainings.

Most of the time we hear the terms like English for civil engineering, English for computing, English for music, English for medicine, English for business, English for Hospitality and so forth. English for hospitality is used for international service industry which is considered under the category of English for specific purposes and its practical application needs to be understood, (Cravotta, 1990). English has dominated many different fields of life such as education, business, technology, media, research, tourism, and medicine (Kaharuddin, A. 2018). According to Tsao and Xu (2008), there is a fast rise and demand for English for specific purposes to achieve people with instrumental purposes. English for specific purposes is recommended to the learners who are required to meet the essential, specific and precise needs to respond to the considerable demands in vocational or academic situations in English (Chang, 2009; Tsao, 2011). For the reasons, Hutchinson and Waters (1987) agreed that one approach to the language teaching is ESP. They believed that all decisions as to the different methods and content are constructed based on the learners' intention and purpose for learning. According to Strevens (1988), ESP is designed and aimed to see the definite needs of the learners. 
As we currently know, the number of hospitality chains in Makassar is significantly increasing. Tribun Timur media reports that during 2012 there were twenty six new hotels opened in Makassar. Also, the international Hospitality Association's report on the challenges facing hotels recommends that employers in the industry ensure adequate training at all levels including improving language tuition, Cooper, Fletcher, Gilbert \& Wanhill in Hobson (1998:9). The main concern in the hospitality industry is the quality and availability of Staff who can speak English well. This problem can be directly linked to hospitality education schools or institutes and university involved. Buttle in Hobson (1998:9) stated that "The hospital industry is a key member of the service sector, delivers a product with three principle components: accommodation, food and beverage."

The beneficial of English as a fundamental element played a significant role in the hospitality business, particularly English for Specific Purposes (ESP). The officers of the hospitality needed to prepare for English skill usage during working. In the hospitality, English used as Franca and it is the most commonly used languages in the hospitality industry worldwide (Blue \& Harun, 2003:77). There are many English terms that are used in Hospitality industry that has a different meaning with the general English, this particular word or phrase in ESP called registers. In English for specific purposes, Vlack (2006:2) describes the main goals in developing a particular curriculum is by teaching students the words which they really need in a particular register.

In a specific situation or group, they might need to work or function. Furthermore, he said that, different groups are going to use obviously different vocabulary items, but are also going to need to use formulaic expression as well as maybe even different structural use of language. Vlack (2006:2) also stated that "In ESP practitioner needs to get a fairly good idea of how the register which they will be trying to teach is actually composed." Swales in Dudley, Evans \& John (1998:80) said that "the importance of the teaching of vocabulary in ESP is now widely accepted." It means that the vocabulary in ESP is important to teach. In addition, Wello \& Nur (1999:15) describe that the ESP teacher's understanding of the content area can be improved in several ways, such as reading books and articles written about the area for the accountant and develop a list of technical terms and their definitions in simple English.

In learning English with a different context specifically, it makes the Hospitality students have to focus and learn more about English in Hospitality term. Sometimes, the students learn English just to get a better achievement. Not only for a better achievement but also some students learn English to prepare himself/herself to get a job in the future, to be an expert in some fields, reputation and many more. And they are aware that English becomes the most essential one that they have to learn. 
They realize that how to communicate or how to understand each other if we do not understand the language, especially in certain community, where English is a targetlanguage community. The reasons previously denote that some students learn or took a course English in a specific way.

As a matter of fact, we realize that there are some problems that faced by the students and teacher in process of teaching and learning English. To analyze the problems, we had conducted a preliminary study on January 2018 at Vocational School 2 Pangkep where in this phase we observed that there were three areas such as the process of teaching and learning English, syllabus and Hospitality English Materials. This step aims to observe and find what the problems that faced the teachers and students in the classroom were. Exceedingly, we found some problems. First, the teacher taught the students to rely on grammar that focuses on the formula of tenses. Consequently, the materials may not contribute to achieve the aims and objectives of the course. It also does not fulfill the students' need and interested, because the material does not relate to their major, which is Hospitality field as the objective of English lesson at Vocational School of Hospitality.

The second problem is the syllabus in which the teacher used only a few materials. It is not enough to cover all of the meetings, and the topics were designed generally and they were specific to the Hospitality phase. It also did not cover the learning goals. The third problem, based on the teachers and students' views, they faced some difficulty such as; they were limited by resources. The teachers have only one source that was a book from the government, where the book was complicated to understand. In addition, the cover design and layout of the book was not clear and attractive because it was not up-to-date, illustration in real pictures then to be taught. In case of teaching English for Hospitality, two English teachers who taught English subject there stated that the course is normally designed based on their intuitions about what they think good for the students to learn in the classroom and not preceded by a needs analysis. Consequently, the syllabus design was not reliable to ensure that the course was appropriate, effective, practical, and realistic to enable the students succeed in both academic and occupational settings, therefore the teachers need more resources that appropriate with the students' need and level of proficiency.

Andi, K., \& Arafah, B. (2017) assume that the first step of every curriculum development, syllabus design and materials development should be needs analysis, i.e. a set of techniques and procedures used for obtaining information about what the learners want and how the learners need to learn in a language program. Therefore, to determine what the students need to achieve through the medium of teaching them English skills. It is 
very important to carry out needs analysis before designing the course syllabus. With regard to the statement, Richards (2001) mentions that different types of students have different language needs and what they are taught should be restricted to what they need. Similarly, Engelmann (1993) affirms that the curriculum applied by the teacher in the classroom interaction must be relevant to the students' needs.

After recognizing the problems as mentioned earlier, we intend to make an effort for solving the problems to develop the quality of English language teaching at Vocational school level by proposing a needs analysis-based syllabus and teaching materials. Such ELT materials are considered appropriate and innovative and are believed able to boost the students' English skills related to their field of study. We are of the opinion that the teachers and students need interesting practical, flexible, understandable, meaningful resources in their English classrooms that suit the learners' needs for the sake of attaining the goals and objectives of the course.

\section{Literature Review}

Many studies have investigated English for Specific Purposes (ESP) and English for hospitality, but only few researchers focus on the English learnt in the Hospitality department. ESP has essential role in learning English that used for academic, professional, and workplace environments for some students. ESP material is designed by doing a deep analysis of what actually the students' needs. There were a lot of researchers reported their research findings of Hospitality in ESP and Developing English Material and syllabus about Hospitality.

Jasso-Aguilar (1999) examined how perceived needs of Hotel maids in a Hotel in Waikiki failed to meet the expectations of the learners' themselves. Stapa \& Jais (2005) examined the failure of Malaysian University courses in Hotel management and Tourism to meet the wants and needs of the students with a lack of skills and genres covered in their courses. Therefore it is clear that needs analysis must include the students input from the beginning of a course design. Stakeholders, institutions and employers often perceive wants and needs differently from students.

Richards (2002:152-164) claims that movements in language teaching approaches and methods have given contributions to syllabus frameworks for language program. Traditional approaches to language teaching (e.g. grammar translation, direct method, aural-oral method) have led to the formulation of traditional syllabus. The simplest level of syllabus can be described as a statement of what is to be learned and the order in which it is to be learned. 


\section{Research Method}

In this case, we firstly have to do literature reviews to be able to start the administration of a preliminary study where to find out the meaning of syllabus contents by examining what kinds of linguistic needs that the students have in order to be taken into account when determining the language components (e.g. grammar, vocabulary functions, skills, etc.) to emphasize syllabus in the Hospitality course. Development research method was used to carry out this study by involving 105 Hospitality students, 2 English teachers as well as 21 hospitality employees. Questionnaires were distributed to obtain data about the needs. The data were then analyzed by frequency, percentage, as well as mean scores. In addition, this also covers Situational Analysis (SA) to disclose what sort of learning needs (e.g. learning preference and learning styles) that the students require being taken into account in selecting teaching techniques and strategies when developing the course materials for Hospitality. All information associated with both the students' linguistic needs and learning needs is analyzed and then drawn up to identify the overall needs required for the syllabus and course contents. The information of the overall needs is then used to set the aims and objectives of the course design.

\section{Result and Discussion}

Based on the objectives of the research, hence the focus here is to find out the students' needs that reflected in the result of the research. It means that after making decision, as well as gathering information from the whole instruments, the syllabus provided can be claimed as the result of the students' needs:

\subsection{The students' needs in learning English of the communicative competence based English materials for Hospitality at Voca- tional School 2 Pangkep}

In this phase, the writer conducted need analysis procedure to identify the linguistic needs and the learning needs of the students of English Education study program. The data of the needs were collected by giving questionnaires to the respondents of this study i.e. the students, the teachers and the graduates. In order to obtain in-depth information on the needs and to across check the data gathered from the questionnaires, interview was also used. 
In gathering information step, the writer used questionnaire contain question which are adopted from Rossert (1982) types of question to assess the needs in the target group. The categories of question are abilities (students' level of proficiency), priorities (language items that considered the most important to learn), priorities (language item that considered the most important to learn), problems (weakness and difficulties in learning), and attitude (participants feeling toward elements of programs.)

\subsubsection{Participant's perceptions about importance of english in hospitality}

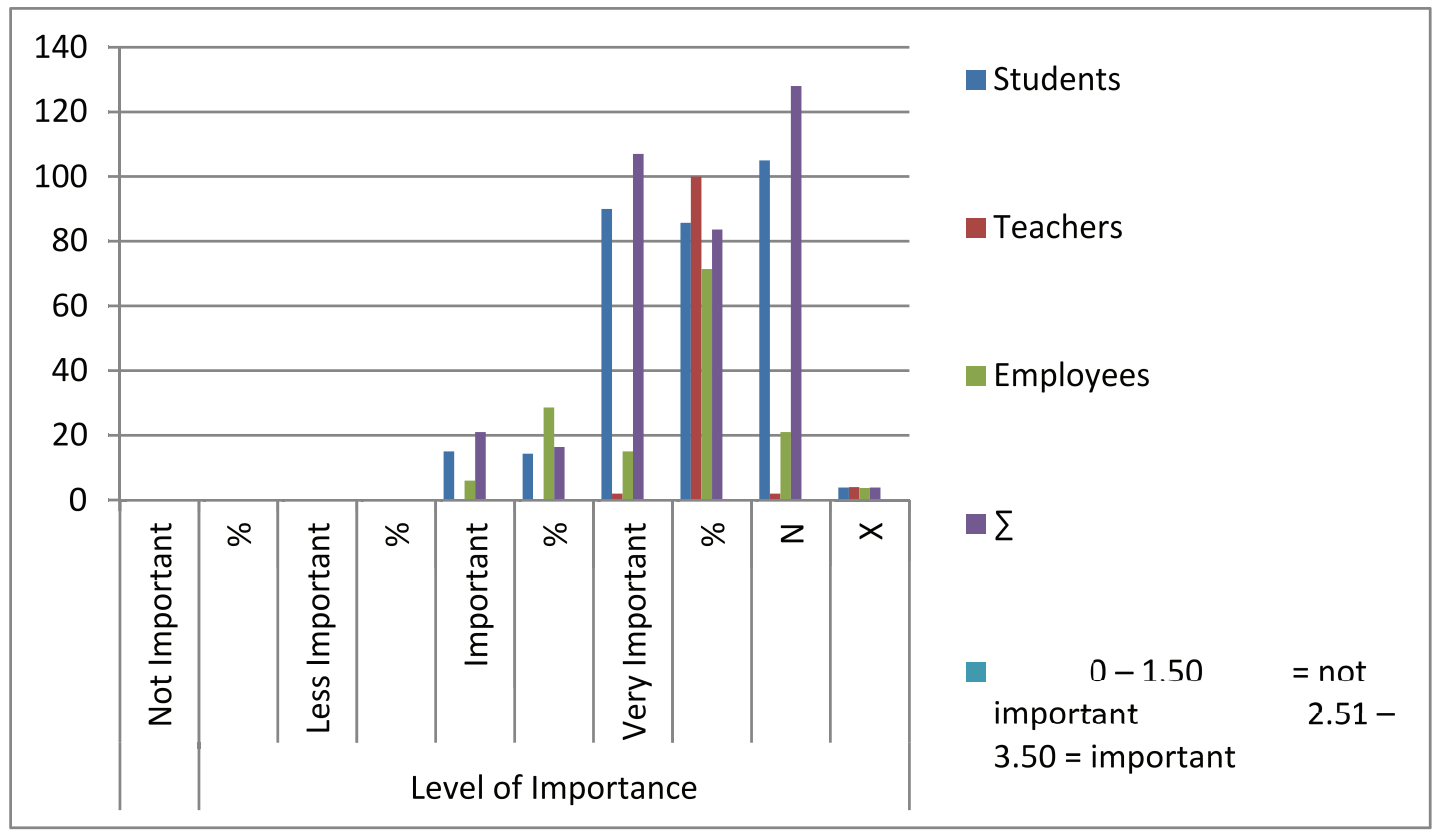

Figure 1: Perceptions about Priority Scale of English in Hospitality.

The above chart gives a breakdown of information on the importance of English subject in Hospitality phase. It illustrates that most of the respondents (107 out of 128 or 83.6\%) selected 'very important' to describe importance of English with total average is 3.84 which describes that the speaking subjects is in the very important level. The first, the student reckons that instructional materials available in speaking practice as indicated by the following students in the interview:

Student 19)

Saya pikir, kemampuan yang kami sangat butuhkan sebagai siswa perhotelan adalah berbicara dalam Bahasa Inggris, maka dari itu kami sangat membutuhkan ruang untuk berlatih berbicara bahasa Inggris untuk memotivasi kita untuk lancar berbicara. (I think, the ability that we exactly need is 
speaking English, therefore we need a place to practice speaking to motivate us to be fluent in speaking.) (Interview, September 19, 2018)

It clearly illustrates that respondents totally realized the necessity of English in Hospitality phases that was performed via questionnaire to elicit respondents' opinion. Hence, the participant reckons that English is a very important pre-requisite for a career in the Hospitality Industry. English language being the language of the world is accepted the formal medium of communication. This fact accepted and endorsed by three groups of participants in Hospitality phases such as Students as a target group, English Teachers as an audience, and graduates as a resource group.

This study also revealed that though students deem English communication as a very vital attribute, most are unable to constructively spend time and effort in improving it. English speaking also leads to confidence of the students. Hence, for success in their field, the issue of internalizing English language needs to be addressed jointly by them. In additions, five reasons of necessity of English come up from students' perspective and graduates as an employees, as indicated by following students in the interview:

Student 17)

Bahasa Inggris tentu sangat penting untuk dipelajari khususnya di Perhotelan. Mengingat jurusan kami erat kaitannya dengan komunikasi, terlebih pada kemampuan berbahasa Inggris. Ini tentu saja akan menunjang karir kami kedepan di Hospitality Industri. Tak hanya di dalam kelas, bahasa inggris kami pelajari pula di luar kelas, seperti mengikuti kursus-kursus di Iuar sana. (English is certainly very important to learn especially in Hospitality. Considering our department is closely related to communication, especially in English language skills. This of course will support our career in the future in the Hospitality Industry. Not only in class, but we also learn English outside the classroom, such as taking courses in outside.) (Interview, September 13, 2018)

A quite similar statement was also found in the interview which was addressed by another student who stated that:

Student 32)

Mempelajari Bahasa Inggris menambah level kepercayaan diri saya dalam berkomunikasi, sebab saya tidak perlu khawatir apakah yang saya sampaikan telah benar atau tidak. Dengan mempelajarinya tentu saya akan paham penggunaannya. (Learning English improves my level of confidence in communication, because I don't need to worry whether what I say is true or not. 
By learning it, of course I will understand its use.) (Interview, September 13, 2018).

Another reckons come up from the graduates who worked in Myko Hospitality and Ibis Hospitality Makassar. The first, she unanimously agreed that English in her field, specifically Front Desk Attendant is very important as indicated by interview at that time:

Graduate 9)

Setelah mengikuti rangkaian interview dan training penerimaan karyawan di Hospitality ini, saya semakin menyadari bahwa bahasa inggris adalah salahsatu penunjang dalam dunia Hospitality. Terlebih saat diberi kesempatan untuk menghadapi tamu-tamu hospitality sebagai Front Desk Attendant, saya pikir ini adalah posisi yang paling krusial dalam penggunaan bahasa inggris itu sendiri, sebab kita harus siap menghadapi tamu-tamu kelas internasional setiap harinya. Berbeda dengan bidang lainnya, mungkin mereka hanya sesekali berhadapan dengan orang aisng, tidak dengan kami yang harus siap berkomunikasi dengan orang-orang asing setiap harinya. Awalnya saya menganggap kemampuan Bahasa Inggris saya sudah mumpuni, ternyata tidak. Saya masih harus banyak belajar, khususnya mempelajari istilah-istilah khusus yang digunakan pada bahasa inggris hospitality. (After taking part in a series of interviews and employee training in this Hospitality, I became increasingly aware that English is one of the fundamental needs in hospitality sector. Especially when given the opportunity to face hospitality guests as the Front Desk Attendant and it is the most crucial position in using English itself, because we must be prepared to face international class guests every day. In contrast to other fields, maybe they only occasionally deal with other people, not with us who have to be ready to communicate with foreigners every day. At first I considered my English ability was qualified, apparently it wasn't. I still have a lot to learn, especially learning specific terms used in English hospitality.) (Interview, September 27, 2018).

As in some results of interview of any fields, this study highlights the importance of English language at not just entry level, but spanning in some phases in Hospitality. The level of importance come up from two reasons of two groups, those were students and graduates. They totally agreed that English is very important in study and their own future career. 


\subsubsection{Participant's perceptions about importance of english in hospital- ity industry}

TABLE 1: Perception about Priority Scale of English Needs for Hospitality Industry.

\begin{tabular}{|l|l|c|c|c|c|} 
No. & Employee Sectors & \multicolumn{3}{|c|}{ Respondent } \\
\hline & Student & Teacher & Employees & \\
\hline $\mathbf{1}$ & Front Desk Attendant & 2.94 & 4.00 & 4.00 & 3.65 \\
\hline $\mathbf{2}$ & House Keeping Department & 3.28 & 3.00 & 3.14 & 3.14 \\
\hline $\mathbf{3}$ & Hospitality Marketing & 3.00 & 4.00 & 3.57 & 3.52 \\
\hline $\mathbf{4}$ & Pastry and Bakery & 2.26 & 2.50 & 3.14 & 2.63 \\
\hline $\mathbf{5}$ & Bartender & 2.40 & 3.00 & 2.86 & 2.76 \\
\hline $\mathbf{6}$ & Chef & 2.77 & 2.50 & 2.29 & 2.52 \\
\hline $\mathbf{7}$ & Bell Driver & 2.14 & 4.00 & 3.29 & 3.14 \\
\hline $\mathbf{8}$ & Telephone Operator (Call Center) & 3.02 & 4.00 & 3.14 & 3.39 \\
\hline $\mathbf{9}$ & Room Service manager & $\mathbf{2 . 6 8}$ & 3.00 & 3.14 & 2.94 \\
\hline & $\mathbf{0 - 1 . 5 0}=$ not important & & $\mathbf{2 . 5 1 - 3 . 5 0}=$ important & \\
\hline & $\mathbf{1 . 5 0}-\mathbf{2 . 5 0}=$ less important & & $\mathbf{3 . 5 1 - 4 . 0 0}=$ very important \\
\hline
\end{tabular}

Source: Primary data processing

In term of priority scale of English needs for hospitality industry from the table above none of the group of participants answered 'less important' and 'not important' in this question point. It means the conclusion from this question was many students dominantly aimed that English is a fundamental thing to be learned in all positions of Hospitality Industry.

As in shown, many respondents stated that all sectors in the hospitality industry immensely need English. From the results of the questionnaires, they appeared that the choice of priority scale was only 'important' and 'very important' in all sectors. Those indicated that English material was very important to be developed in hospitality and adjust their needs in these fields. These ideas married up naturally with the development of English courses for specific groups of learners. The idea was simple: if language varies from one situation of use to another, it should be possible to determine the features of specific situations and then make these features the basis of the learner's course.

In short, the view gained ground that the English needed by a particular group of learners could he identified by analyzing the linguistic characteristics of their specialist area of work or study. 'Tell me what you need English for and I will tell you the English that you need' became the guiding principle of ESP (Hutchinson and Waters, 1987: 8). Among the factors that could explain its vitality and its expansion is, as previously mentioned, the emergence of English as a world language, for this reason the necessity to cope with the different teaching situations and needs that such a position brings about. Such 


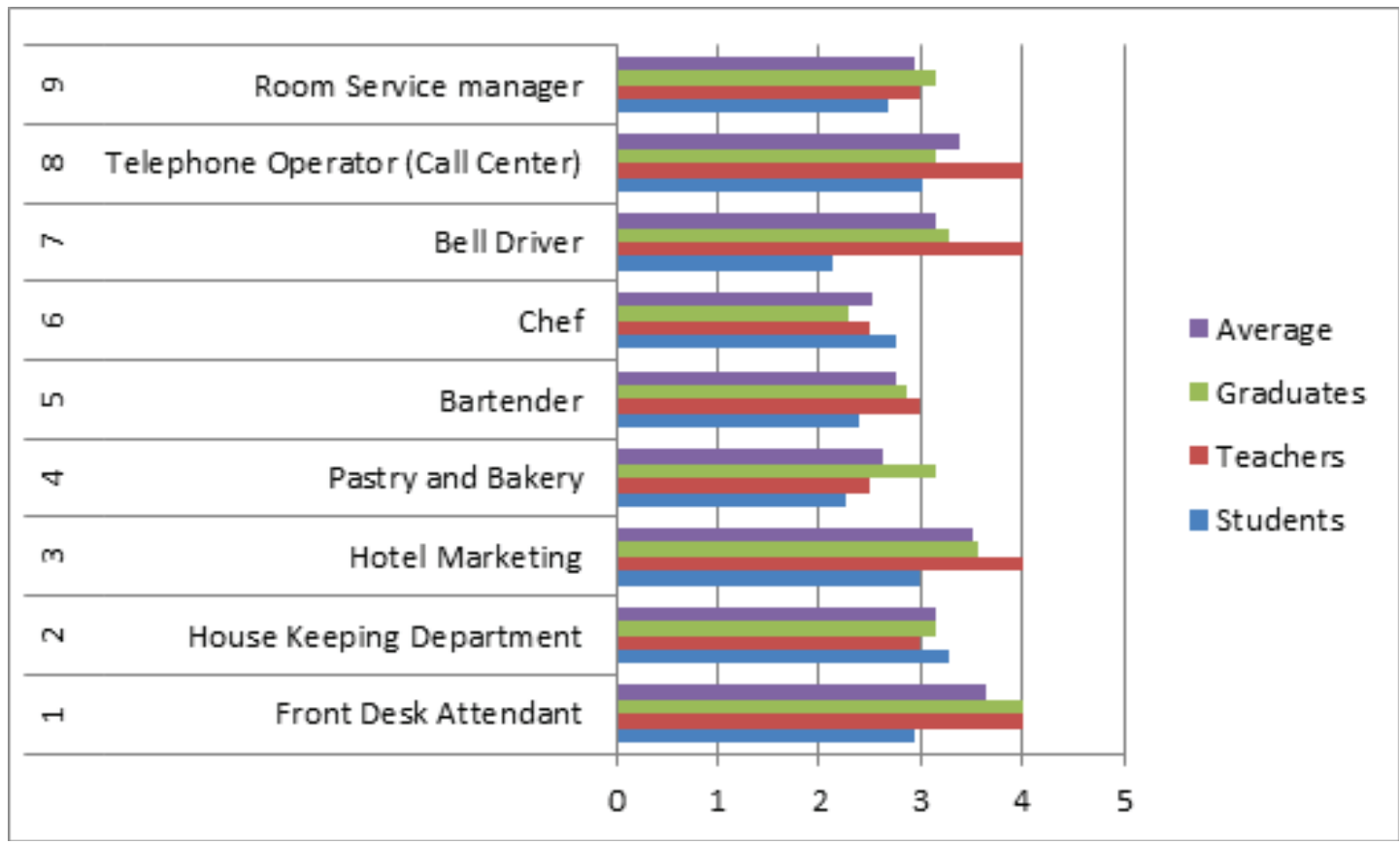

Figure 2: Perception about Importance of English in Hospitality Industry.

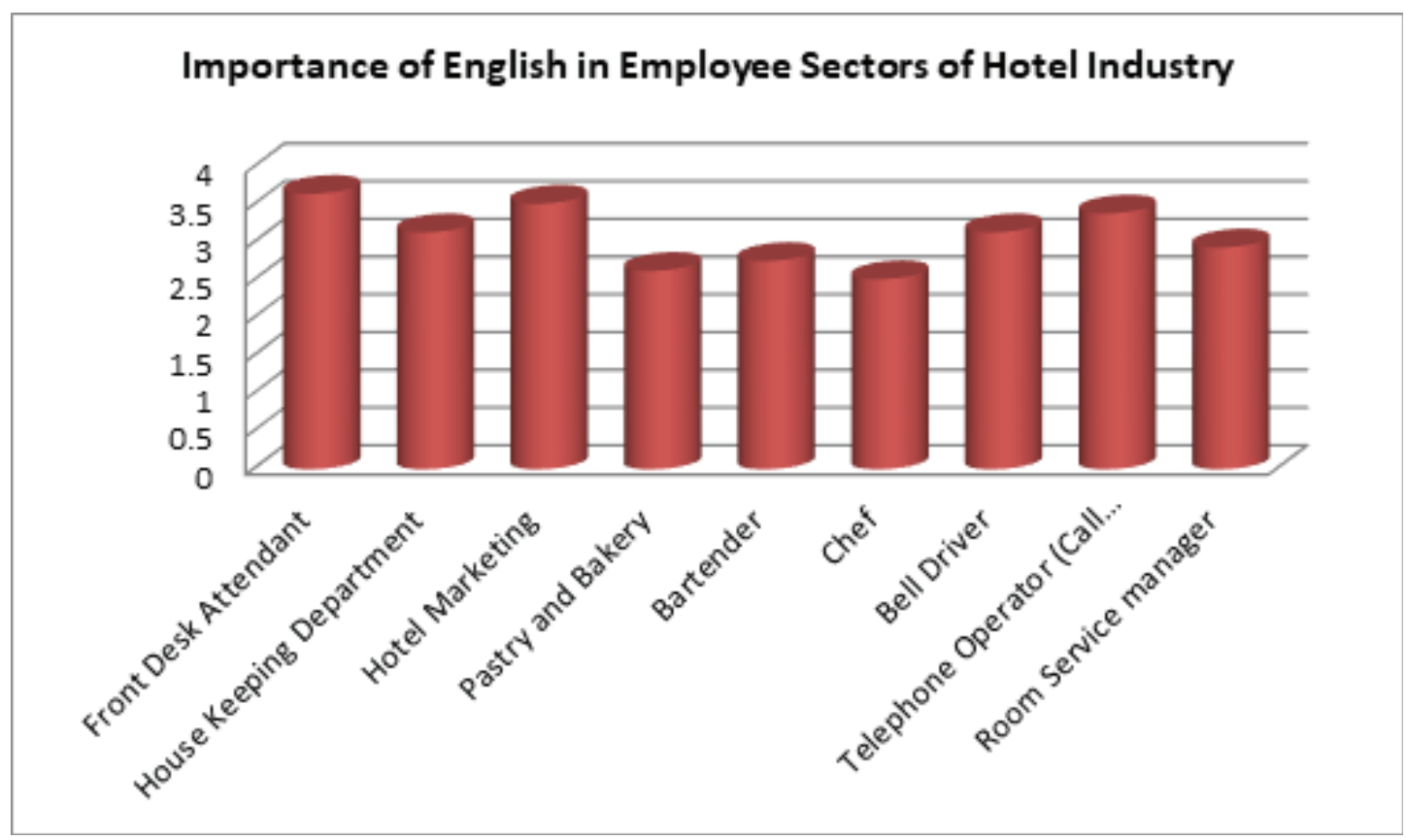

Figure 3: Perception about Importance of English in Hospitality Industry.

necessity implies an understanding of its development, types and the different teaching concepts of ESP. However, it is of great importance to start with the main definitions stated by the linguists concerning ESP. Apparent variations in the interpretation of ESP definitions can be observed; some people described ESP as simply being the teaching of English for any purpose that could be specified in their own positions.

\section{Description of the Students' Learning Needs in General}




\section{a. Participant's Perceptions about English Learning Goals of English in Hospitality}

TABLE 2: Perception on the Importance of English Learning Goals in Hospitality.
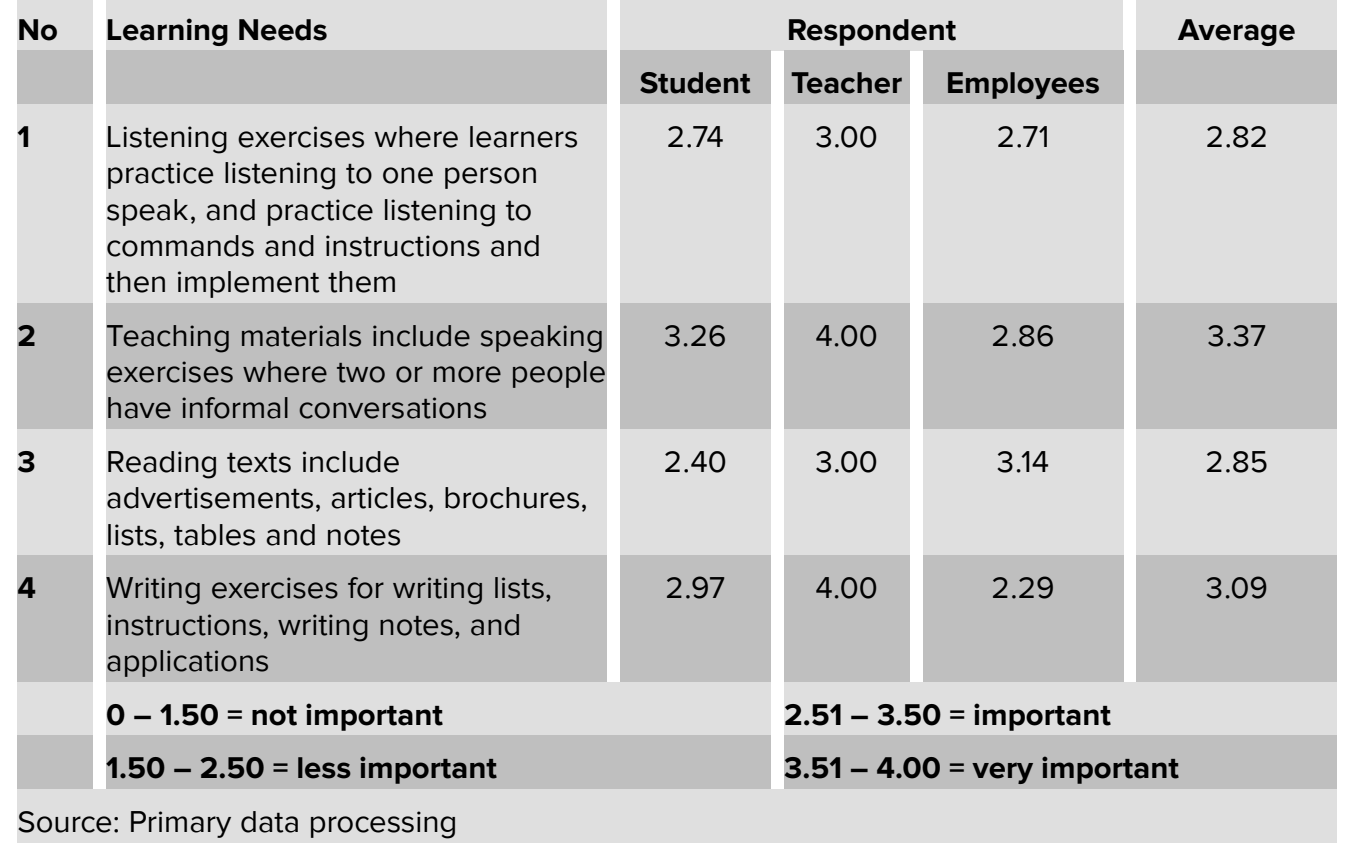

Falling back on the data presented in essential purposes of Learning English in Hospitality, the result on above data supported the statement that the language we speak and write varies considerably in a number of different ways, from one context to another depending on who speaks to whom, when, what and where to speak. So, one's register shows what you are doing (Hudson,1980: 45), here that refers to four English learning skill goals, specifically i.e. Listening exercises where learners practice listening to one person speak, and practice listening to commands and instructions and then implement them (3.37), it was in important level. Teaching materials include speaking exercises where two or more people have informal conversations (2.82), means that it was in important level. Also, Reading texts include advertisements, articles, brochures, lists, tables and notes was in important level, the mean was (2.85). As well, writing exercises for writing lists, instructions, notes, and applications was in important level and the score average attainment was higher than speaking and reading skills (3.09).

Based on the above chart, it clearly seems that the students prefer into two skills in English such as speaking and writing. The students need to improve their ability in both skills in learning English for specific purposes that can help them to communicate in spoken and writing English. From the data presented in table 3, it is obviously seen that speaking in the top position of the average score (3.37) which belong to important category. Moreover, writing skill also put forward than reading and listening skill. So 


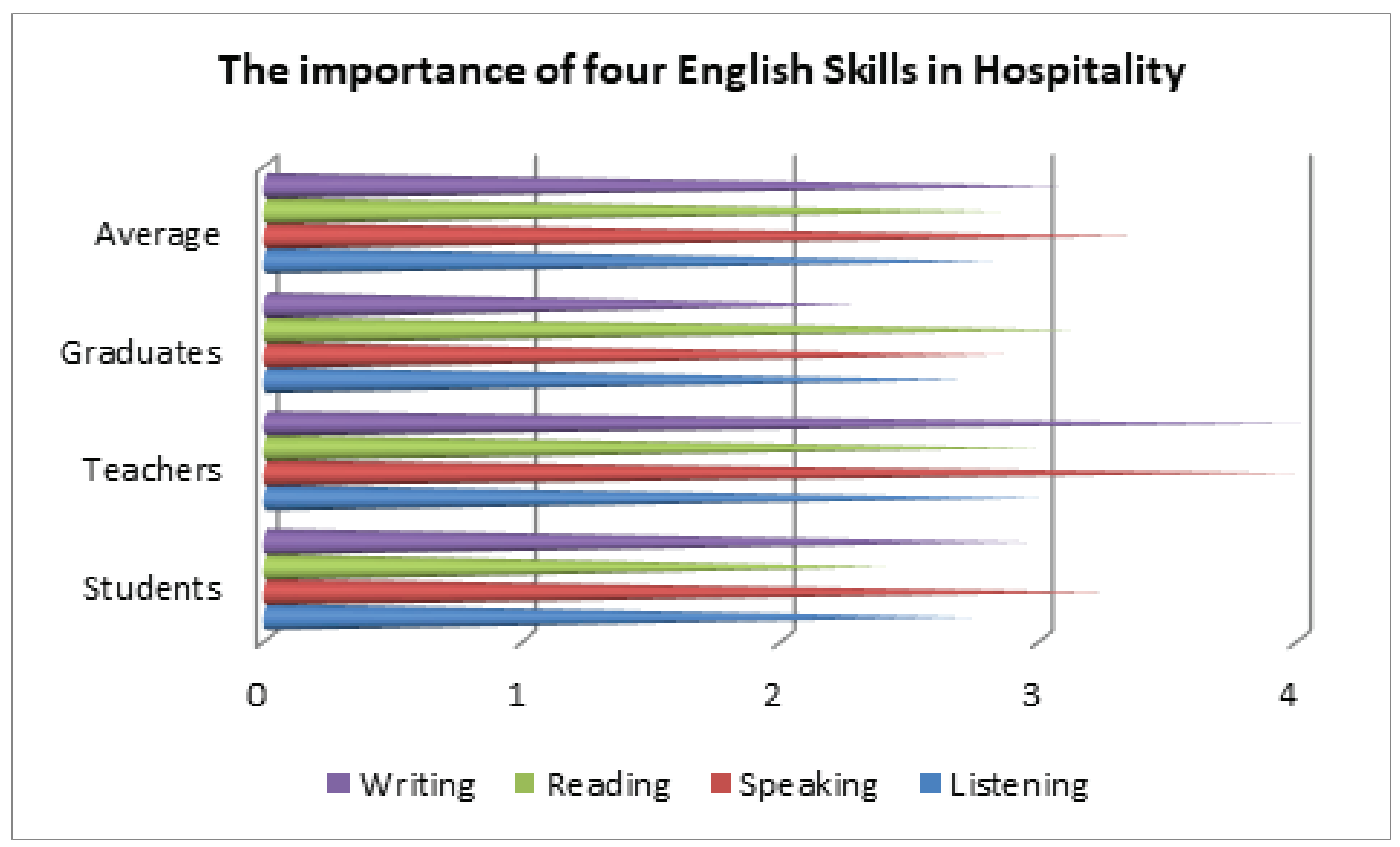

Figure 4: Perception about Priority Scale of English Skills in Hospitality.

that, writing reached the second position after speaking skill with average score quite similar (3.09). This reason was also stated by both student and graduate in interview:

Student 29)

Saya pikir kemampuan berbicara bahasa inggris sangat penting dari kemampuan yang lainnya, karena di dunia kerja kita akan menghadapi orang-orang yang tak hanya orang Indonesia. Oleh karena itu, kemampuan berbicara bahasa inggris sebagai bahasa internasional sangatlah penting. (I think speaking skill is very important than other skills, because we will face different man from different communities besides Indonesian. So that, English as international language is very important.) (Interview, September 13, 2018).

The other pronouncement stated by graduate in interview:

Graduate 7)

Saat ini saya bekerja pada bidang Marketing Hospitality, dimana berbicara dalam bahasa inggris sangat saya butuhkan. Karena selain bertemu orangorang yang menggunakan bahasa inggris, saya juga diharuskan menguasai bahasa inggris untuk mempresentasikan atau menjawab pertanyaanpertanyaan klien dengan bahasa inggris yang baik. Tentu saja dengan memiliki kemampuan berbicara yang baik, modal untuk menarik klien ataupun presentasi kerjasama akan semakin sukses. Tak hanya berbicara 
bahasa inggris, namun kemampuan menulis juga dibutuhkan dalam menyusun draft presentasi. Tulisan yang baik juga penentu suksesnya jalan presentasi. (I am currently working in the Hospitality Marketing field, where I need to speak English well. Besides meeting people who speak English, I also have to master English to present or answer client questions with good English. Therefore, by having good speaking skills, it is easy to attract clients or the presentation of cooperation will be more successful. Not only speak English, but writing skills are also needed in preparing a draft of presentations. Good writing also determines the success of the presentation path.) (Interview, September 27, 2018).

Basically, the language domains are speaking, listening, writing and reading. Laborda (2009) makes a definition for each of the language domains. According to Laborda (2009), in speaking, a learner has to engage in oral communication in different situations purposely. Listening is the process of understanding, interpreting and evaluating spoken language in a variety of situations. Writing is being engaged in written communication in various forms purposely, and reading is the process of interpreting and evaluating the written language symbols and text with understanding and fluency.

As mentioned reasons previously by the students and graduates that writing skill was needed in preparing a draft of presentations and good writing also determines the success of the presentation path. Falling back on the interview data presented by graduate 7 previously that based on her experience in working on Hospitality industry, writing skill was a one of fundamental thing to be mastered. Especially in some sectors of hospitality employees such as front desk attendant, hospitality marketing and room service manager are necessity to learn.

Through out of the learning need goals presented in questionnaires, all both students and graduates make effort to improve their speaking and writing skills so that they can maximize their own presentation using English where speaking skill needed teaching materials included speaking exercises where two or more people have an informal English Conversation. Besides speaking skill, it is also needed to develop the capabilities of exercise for writing lists, instructions, writing notes, and applications in term of hospitality administrations such as announcement in English.

\section{Description of Students' Learning Ability}

\section{a. Ranking of participant's Perceptions about Reading Level of Proficiency}

In the above table 6 , scanning and skimming took a position in the top, followed spelling as a second position, guessing the meaning as the third and the last position 
TABLE 3: Perceptions about their Reading Level of Proficiency.

\begin{tabular}{|c|c|c|c|c|c|}
\hline & \multirow[t]{2}{*}{ Reading Components } & \multicolumn{3}{|c|}{ Respondent } & \multirow[t]{2}{*}{ Average } \\
\hline & & Student & Teacher & Employees & \\
\hline 1 & Scanning and Skimming & 2.43 & 2.00 & 2.86 & 2.43 \\
\hline 2 & Spelling & 2.51 & 2.00 & 2.71 & 2.41 \\
\hline 3 & Grammatical & 2.40 & 2.00 & 2.71 & 2.37 \\
\hline \multirow[t]{3}{*}{4} & Guessing the Meaning of the Words & 2.37 & 2.00 & 2.71 & 2.36 \\
\hline & \multicolumn{2}{|l|}{$0-1.50=$ Poor } & \multicolumn{3}{|c|}{$2.51-3.50=$ Good } \\
\hline & \multicolumn{2}{|l|}{$1.50-2.50=$ Fair } & \multicolumn{3}{|c|}{$3.51-4.00=$ Excellent } \\
\hline
\end{tabular}

was grammatical component. Grammatical was in 'poor' level, the mean was (2.37). Scanning and skimming was in 'fair' level, the mean was (2.43). Guessing the meaning of the words was in 'fair' level, the mean was (2.36). In the below chart 4 , it clearly shows that the top position taken by spelling and skimming with a total percentage $26 \%$, followed grammatical, scanning and skimming with a quite similar percentage (25\%), and also guessing the meaning of the words (24\%).

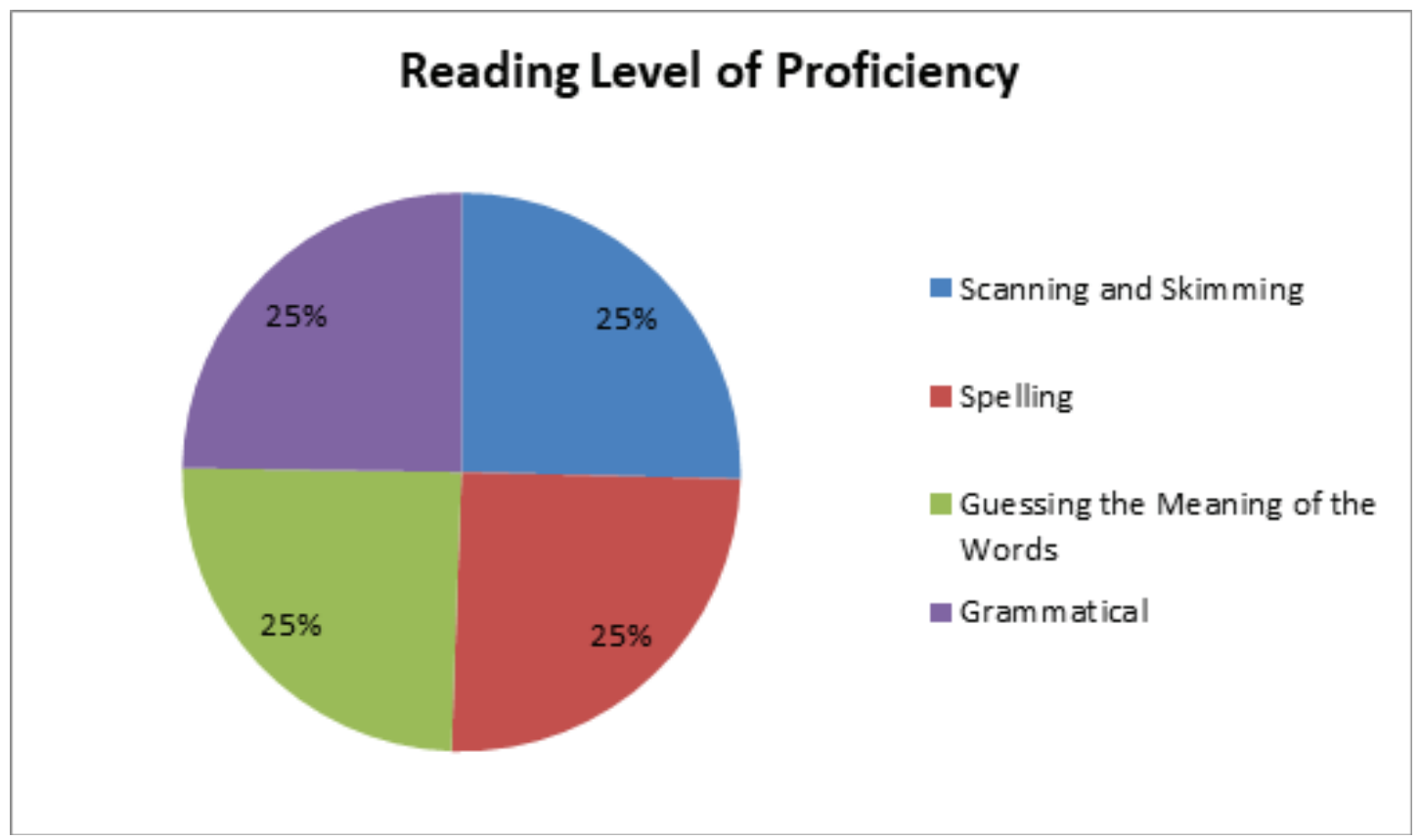

Figure 5: Perceptions about their Reading Level of Proficiency.

As can be observed here, a significant number of students felt that they were lack of all components of reading skill. It means that all in all are in fair level of proficiency so that among them are not available because of mean scores not reached off.

According to the students, guessing skimming and scanning is felt unsatisfactory due to the students' tendency to have less attention to learn in Reading activity. Most of them 
are of the opinion that both are obstacles for them in Reading (as stated by student 9 in interview). However, the students' statement may not be interpreted as an effort to ignore skimming and scanning entirely in the reading activity, but this can serve as a good input for the syllabus and material development in Hospitality.

From the result of analysis of the respondents' perceptions on language components and the students' proficiency level in the four areas of reading components, we found that skimming and scanning, spelling, grammatical, and guessing the meaning of the words have to be taken into consideration as a cornerstone to design the speaking course one syllabus by looking at the following conditions:

1. Skimming and scanning are considered very important to be given in reading activity. This level of importance is determined based on the average score attained by the two components in which skimming and scanning achieves 2.43 . This condition requires the syllabus and material development as the first priority in each lesson.

2. It closely similar with another components such as spelling, grammatical and guessing the meaning activities was considered very important, even the portion has to be different in presenting at each lesson.

\section{b. Ranking of participant's Perceptions about Speaking Level of Proficiency}

TABLE 4: Perceptions about their Speaking Level of Proficiency.

\begin{tabular}{|c|c|c|c|c|c|}
\hline \multirow[t]{2}{*}{ No } & \multirow{2}{*}{$\begin{array}{l}\text { Speaking } \\
\text { Component }\end{array}$} & \multicolumn{3}{|c|}{ Respondent } & \multirow[t]{2}{*}{ Average } \\
\hline & & Student & Teacher & Employees & \\
\hline 1 & Pronunciation & 2.57 & 2.00 & 2.14 & 2.24 \\
\hline 2 & $\begin{array}{l}\text { Accuracy and } \\
\text { Fluency }\end{array}$ & 2.29 & 2.00 & 2.29 & 2.19 \\
\hline 3 & Vocabularies & 2.29 & 2.00 & 2.14 & 2.14 \\
\hline \multirow[t]{3}{*}{4} & Grammatical & 2.20 & 2.00 & 2.14 & 2.11 \\
\hline & \multicolumn{2}{|l|}{$0-1.50=$ Poor } & \multicolumn{3}{|c|}{$2.51-3.50=$ Good } \\
\hline & \multicolumn{2}{|l|}{$1.50-2.50=$ Fair } & \multicolumn{3}{|c|}{$3.51-4.00=$ Excellent } \\
\hline
\end{tabular}

As shown in the table 7 above, the top level of components in speaking skill of students was pronunciation. Then, it followed by accuracy and fluency, vocabulary and the last was grammatical. An overwhelming majority stated that most of students were 'fair' in speaking ability. Vocabulary was in (2.14), pronunciation was in (2.24), grammatical was in (2.11), accuracy and fluency was also in fair level (2.19). The striking point about these results is that students less of speaking proficiency. 
For the reason in this presents information about the variety components, the writer divided in four areas, those conditions are:

1. Pronunciation as the first urgently present component to be given in speaking activity which was in 2.24 average score. This is to conclude that pronunciation should be put in material development.

2. Accuracy and fluency was also in fair level, meaning that practicing speaking is totally needed. Besides, it can be presented reading material such as conversation or dialogue that integrated to the hospitality phase.

3. Similarly, it is also needed to scaffold the vocabulary or Hospitality terminology in the first activity as a builder item and grammar components at the end of each lesson.

\section{c. Ranking of participant's Perceptions about Listening Level of Proficiency}

TABLE 5: Perceptions about their Listening Level of Proficiency.

\begin{tabular}{|c|c|c|c|c|c|}
\hline \multirow[t]{2}{*}{ No } & \multirow[t]{2}{*}{ Listening Component } & \multicolumn{3}{|c|}{ Respondent } & \multirow[t]{2}{*}{ Average } \\
\hline & & Student & Teacher & Employees & \\
\hline 1 & Retaining the Content & 3.03 & 2.00 & 2.43 & 2.49 \\
\hline 2 & Identifying the Structure & 2.54 & 2.00 & 2.43 & 2.32 \\
\hline 3 & Detecting Biases & 2.51 & 2.00 & 2.43 & 2.31 \\
\hline 4 & Critically Evaluating & 2.46 & 2.00 & 2.43 & 2.30 \\
\hline \multirow[t]{3}{*}{5} & Weeding Irrelevant & 2.43 & 2.00 & 2.43 & 2.29 \\
\hline & \multicolumn{2}{|l|}{$0-1.50=$ Poor } & \multicolumn{3}{|c|}{$2.51-3.50=$ Good } \\
\hline & \multicolumn{2}{|l|}{$1.50-2.50=$ Fair } & \multicolumn{3}{|c|}{$3.51-4.00=$ Excellent } \\
\hline
\end{tabular}

From the data presented in table 8 , in the ranking of the highest ability of students in the elements in listening, the highest is retaining the content (2.49), followed by identifying the structure (2.32), detecting biases (2.31), critically evaluating (2.30) and the last was weeding irrelevant (2.29). The results for this item suggest that respondents were generally willing to choose 'fair' level to describe their own listening ability.

From the result of analysis of the respondents' perceptions on language components and the students' proficiency level in the five areas of listening components, we found that retaining the content, identifying the structure, detecting biases and critical evaluating have to be taken into consideration as a cornerstone to design the listening course one syllabus by looking at the following conditions:

1. Retaining the content is considered very important to be given in listening activity This level of importance is determined based on the average score attained by the 
two components in which skimming and scanning achieves 2.49 . This condition requires the syllabus and material development as the first priority in each lesson.

2. It closely similar with another component such identifying the structure, detecting biases and critical evaluating were considered very important, even the portion has to be different in presenting at each lesson.

\section{d. Ranking of participant's Perceptions about Writing Level of Proficiency}

TABLE 6: Perceptions about their Writing Level of Proficiency.

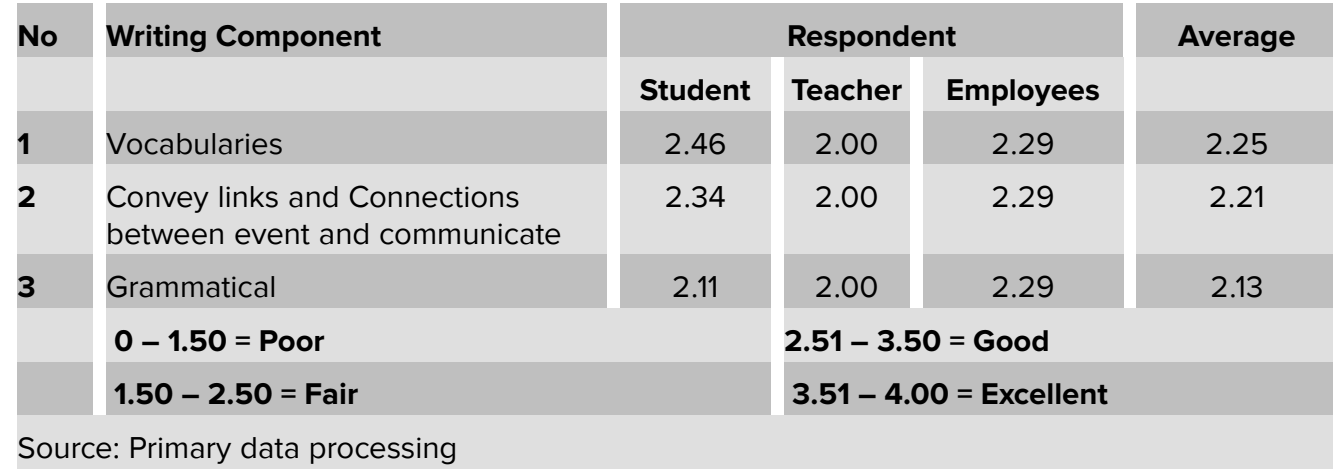

According to the data in table 9 , it shows that the top ability of writing components was vocabularies (2.25), in order to convey links and connections between events and communicate (2.21), and the last was grammatical (2.13).

For the reason in this presents information about the variety components, the writer divided in four areas, those conditions are:

1. Vocabulary as the first urgently present component to be given in writing activity which was in 2.25 average score. This is to conclude that pronunciation should be put in material development.

2. Convey links and connections between events and communicate was also in fair level, meaning that need to practicing some terms related into Hospitality term in currently topics is totally needed.

3. Similarly, it is also needed to scaffold the grammar components at the end of each lesson.

\section{Description of Students' Learning Priority}

\section{a. Ranking of participant's Perceptions about Reading Level of Proficiency}

Table 10 shows the most needed elements or components within reading phase was grammatical and guessing meaning of the word. It received the highest degree of 
TABLE 7: Perceptions on the Importance of Reading Skill Component.

\begin{tabular}{|c|c|c|c|c|c|}
\hline \multirow[t]{2}{*}{ No. } & \multirow[t]{2}{*}{ Reading Component } & \multicolumn{3}{|c|}{ Respondent } & \multirow[t]{2}{*}{ Average } \\
\hline & & Student & Teacher & Employees & \\
\hline 1 & Grammatical & 2.71 & 4.00 & 3.14 & 3.28 \\
\hline 2 & Guessing the Meaning of the Words & 3.11 & 3.00 & 3.14 & 3.08 \\
\hline 3 & Scanning and Skimming & 2.60 & 3.00 & 3.14 & 2.91 \\
\hline \multirow[t]{3}{*}{4} & Spelling & 2.54 & 2.00 & 3.14 & 2.56 \\
\hline & \multicolumn{2}{|l|}{$0-1.50=$ not important } & \multicolumn{3}{|c|}{$2.51-3.50=$ important } \\
\hline & \multicolumn{2}{|l|}{$1.50-2.50=$ less important } & \multicolumn{3}{|c|}{$3.51-4.00=$ very important } \\
\hline
\end{tabular}

evaluation and importance in reading area. Most of the respondents in the three groups emphasized positively in the quite similar response in choosing all components needed to be improved.

\section{b. Ranking of participant's Perceptions about Speaking Level of Proficiency}

TABLE 8: Perceptions on the Importance of Speaking Skill Component.

\begin{tabular}{|c|c|c|c|c|c|}
\hline \multirow[t]{2}{*}{ No. } & \multirow[t]{2}{*}{ Speaking Component } & \multicolumn{3}{|c|}{ Respondent } & \multirow[t]{2}{*}{ Average } \\
\hline & & Student & Teacher & Employees & \\
\hline 1 & Pronunciation & 3.40 & 4.00 & 3.43 & 3.61 \\
\hline 2 & Vocabularies & 2.89 & 4.00 & 3.57 & 3.49 \\
\hline 3 & Grammatical & 2.60 & 4.00 & 3.29 & 3.30 \\
\hline \multirow[t]{3}{*}{4} & Accuracy and Fluency & 2.69 & 4.00 & 3.00 & 3.23 \\
\hline & \multicolumn{2}{|l|}{$0-1.50=$ not important } & \multicolumn{3}{|c|}{$2.51-3.50=$ important } \\
\hline & \multicolumn{2}{|l|}{$1.50-2.50=$ less important } & \multicolumn{3}{|c|}{$3.51-4.00=$ very important } \\
\hline
\end{tabular}

Data in table 11 reveals that majority of respondents in this study chose 'pronunciation' (3.61) as the crucial thing in speaking components, followed by 'vocabularies' (3.49) was that the result of important scale is available because of mean scores reached off. Moreover, above data might be considered to be developed. In addition, the data interview data collections from three groups of respondent was that mentioned reasons previously by the students and graduates that speaking skill is very important skill because of the speaking skill needed teaching materials included speaking exercises where two or more people have an informal English Conversation. Look at the table 3 , chart 3 and the statement of student 29 , also graduate 7 .

After discussing with both teachers who taught English subject there, they aimed that speaking course is really helpful for hospitality students in future career, so that it is very necessary to include linguistic needs specifically in students' speaking abilities. It 
makes sense to discuss the speaking component which is needed in English because speaking ability greatly supports good speaking skills. Hence, examples of English conversation in hospitality industry were also very much needed.

In term of pronunciation and vocabulary needed, the majority questionnaire result shows that many cases of misunderstanding in oral communication were caused by improper pronunciation such as mispronouncing words, for example when the student pronounces the words like snack and snake, it can be lead to a misunderstanding. This statement is associated with one of students' opinion conveyed in the interview:

Student 29)

Menurut saya, pengucapan sangat penting untuk dipelajari karena kita tahu bahwa beda pengucapan maka beda pula artinya. Banyak yang salah paham atau keliru dengan pembicaraan dalam bahasa inggris disebabkan oleh kesalahan dalam pengucapan. Banyak diantara teman saya yang sanggup berbicara bahasa inggris dengan lancar namun apa yang mereka sampaikan hanya sedikit dimengerti atau tidak sama sekali. (In my opinion, pronunciation is very important to learn because we know that different pronunciations are different in meaning. Many people misunderstand or mistakenly speak in English due to errors in pronunciation. Many of my friends were able to speak English fluently but what they said was only a little understood or not at all.) (Interview, September 27, 2018).

In the statement above, it clearly shows that pronunciation is needed to be learned for the students. Moreover, we need to emphasize that achieving good pronunciation doesn't mean to have native-speaker like pronunciation because of our accent in pronunciation is part of our culture and we may not lose it entirely. Having good pronunciation reflect what we call "comfortable intelligibility." In other words, the interlocutors listening to us able to understand what we are saying that communication takes place effectively.

In the midst of the increasingly urgent English, there are around 700 variations of English in the world called Englishes. Included in this variation are English that is used daily in Malaysia (Manglish) and in Singapore (Singlish), Korean English, and Iraqi English. Based on this, English does not have to be like American, English, and Australian English. In this regard, Hikmawati (2016) revealed, "It is a longer necessary to look at the variety of our models to be followed." We have our own indigenous varieties that suit our purposes. 
Thus, the Indonesian people must begin to use English sourced from the Indonesian as their mother tongue that Indonesian English and even Batak English, Madurese English, Papuan English, Buginees English and others will be born. The psychological barrier that English must be like English Obama or Beyonce, for example, must be eliminated by developing our own English. What is important is to use English in unlimited space and opportunities, regardless of pronunciation and grammatical errors. Such conditions are created in Malaysia and Singapore so that the use of English is widespread.

For the initial learning phase, the use of English without questioning pronunciation and grammatical errors is seen as very appropriate and can be done by everyone, especially in schools and campuses. For the next stage, achieving proficiency using English in negotiations, speeches, concepts of memoranda of understanding, seminars, and writing of scientific papers (English for Specific Purposes), intensive and planned training and learning in schools is needed

In sum up, accuracy and fluency are element of language which also exists in speaking. So that among pronunciation, accuracy and fluency are needed to be develop here in this study.

\section{c. Ranking of participant's Perceptions about Importance of Listening Skill Com- ponent}

TABLE 9: Perceptions on the Importance of Listening Skill Component.

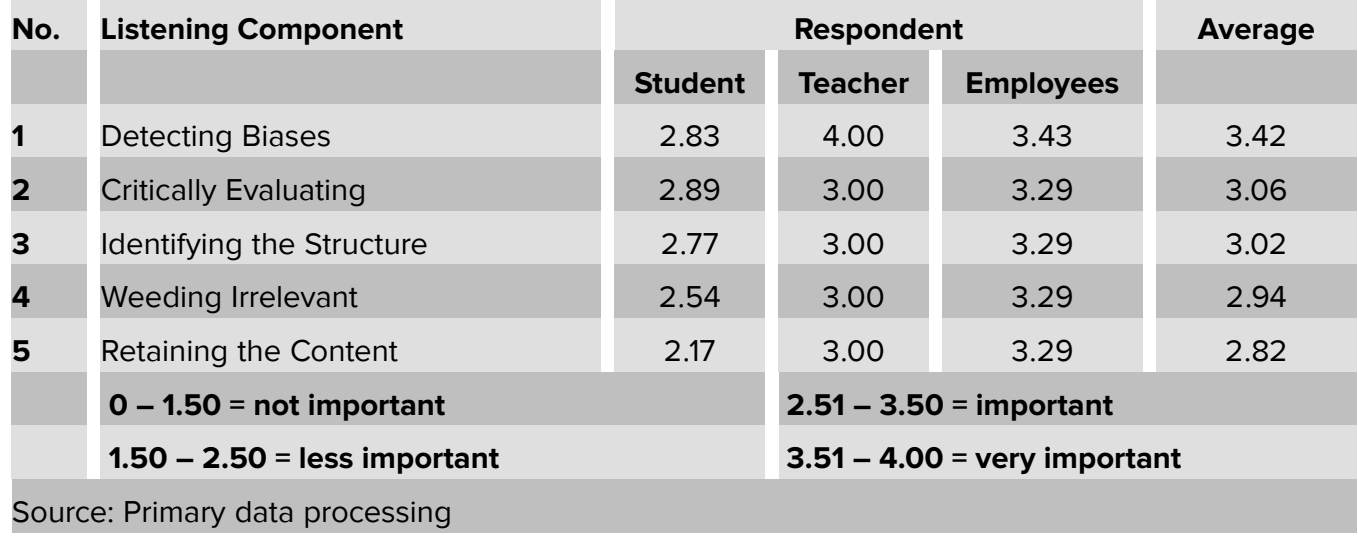

Table 12 describes the respondent's perspective about the importance of listening components, so that we could take a look at the top average showed here were three components, those were detecting biases (3.42), critically evaluating (3.06), identifying the structure (3.02). Falling back on the data presented in a chart 3, it showed that the result of important scale was not available because of mean scores not reached off. After discussing with the teachers, they said that it was not really useful for their future 
career, but however they need it in both employment and academic phases, especially in national examination.

Moreover, above data might be revised or considered by interview data collections from three groups of respondent:

\section{Teacher 2)}

Saya pikir penting, karena listening tetap masuk kriteria penilaian. Kalaupun tidak dijadikan prioritas atau core skill, tetap dimasukkan sebagai skill penunjang atau sebagai flow skill. Bagaimanapun, mempelajari speaking tentu kemampuan listening mengikut, jadi tetap dibutuhkan. (I think it is important, because listening is still included in the assessment criteria in curriculum. Even if it is not a priority or core skill, it is still included as a supporting skill or as a flow skill. However, learning speaking certainly has the ability to listen, so it is still needed.) (Interview, September 13, 2018).

Student 3)

Kalau melihat kebutuhan pekerjaan kedepan, listening tidak begitu penting, namun tidak bisa dipungkiri bahwa kemampuan mendengarkan tetap menjadi kriteria ujian nasional dan bagaimanapun kita wajib mengadapinya. Jadi, tetap perlu dimasukkan dalam proses pengajaran, apalagi mengingat kemampuan mendengar rata-rata siswa disini tergolong rendah. (If you look at the need for work in the future, listening is not very important, but it cannot be denied that listening ability remains a criterion for national examination and however we are obliged to deal with it. So, it still needs to be included in the teaching process, especially considering the average listening ability of students here is low.) (Interview, September 13, 2018).

Graduate 5)

Diantara empat kemampuan bebahasa inggris, listening tak begitu penting, namun tetap saja dijadikan uji kompetensi di sekolah. (Among the four English language skills, listening is not very important, but it is still used as a competency test in schools.) (Interview, September 27, 2018).

From the statement above, we can obviously know that listening skill still needed in learning process. However, listening skill is one of criterion element in school curricula where will be clearly tested on the national exam later.

\section{d. Ranking of participant's Perceptions about Importance of Writing Skill Compo- nent}


TABLE 10: Perceptions on the Importance of Writing Skill Component.

\begin{tabular}{|c|c|c|c|c|c|}
\hline \multirow[t]{2}{*}{ No. } & \multirow[t]{2}{*}{ Writing Component } & \multicolumn{3}{|c|}{ Respondent } & \multirow[t]{2}{*}{ Average } \\
\hline & & Student & Teacher & Employees & \\
\hline 1 & Vocabularies & 3.26 & 4.00 & 2.00 & 3.09 \\
\hline 2 & $\begin{array}{l}\text { Convey links and Connections } \\
\text { between event and communicate }\end{array}$ & 2.69 & 4.00 & 2.00 & 2.90 \\
\hline \multirow[t]{3}{*}{3} & Grammatical & 2.54 & 4.00 & 2.00 & 2.85 \\
\hline & \multicolumn{2}{|l|}{$0-1.50=$ not important } & \multicolumn{3}{|c|}{$2.51-3.50=$ important } \\
\hline & \multicolumn{2}{|l|}{$1.50-2.50=$ less important } & \multicolumn{3}{|c|}{$3.51-4.00=$ very important } \\
\hline
\end{tabular}

In the data above, the top element as a necessity is a vocabulary or terminology related into hospitality phase. In addition, writing on applied linguistics generally, Fairclough (1992) critiques the notion of teaching appropriate language use for two reasons. First, it implies the existence of a culturally homogeneous speech community. In fact, real speech communities and demonstrate cultural heterogeneity. Second, it promotes normativity and training. In place of teaching appropriate language use, language education should try to help learners develop critical language awareness. The advantage of such awareness is that learners will be positioned to choose which language practices they wish to engage in and which they wish to modify or reject:

Critical language awareness... should not push learners into oppositional practices which condemn them to disadvantage and marginalization; it should equip them with the capacities and understanding which are preconditions for meaningful choice and also effective citizenship in the domain of language. (Fairclough, 1992, p.54).

In the field of vocational school, EAP that used in the classroom activity was not suitable to be applied, conventionally adhering to view in which teaching has tended to assume the ubiquity of patterns, skills, and procedures. It was totally denoted as EAP course where participants. So when students and academics from other parts of the world are found not to share these, EAP has tended to fault the participants for thinking in 'illogical,' 'vague,' and 'unclear ways' and failing to give regards to diverse ways of thinking, because EAP is too structured and does not give students reproach for being more creative.

This statement is associated with one of students' opinion conveyed in the interview:

Teacher 1)

Sejauh ini, buku Bahasa Inggris pegangan guru maupun siswa yang kami terima dari kemendikbud memang buku General English, yang berlaku untuk 
semua kalangan sekolah menengah baik SMA, MA, SMK, MAK, itu semua menggunakan buku pegangan yang sama. Konten materi berlaku secara umum dan tidak dikhususkan. (As long as the English language books for teachers and students that we have received from the Ministry of Education and Culture are indeed General English books, which applied to all students from overall high school, MA, SMK, MAK, all of them use the same handbook. Material content is general and not specified.) (Interview, September 13, 2018).

Regarding the above statement, we can synchronize the fact that the teacher and student handbook used in the school still used General English where the ESP character is omitted. Learning seems monotonous and unrealistic because it was not taken the background knowledge where it could deliver students to be more critical in the learning process. That is why, to say in writing, instructions that are inappropriate and too binding, so that there is no chance of students to explore their abilities in raising ideas that were in line with the characteristics of ESP itself.

\section{e. Ranking of participant's Perceptions about Topic to be included in the Syllabus Design}

Based on the data table 14, showed that all topics of important scale were available because of mean scores reached off so that there are eighteen topics that to be included in the syllabus design. The topics selected have average score range from 2.6 to 3.55 . The topics could then be listed into order according to level of importance as follows:

1. Greeting and Receiving Guests (3.55 = very important)

2. Using the Telephone (3.49 = important)

3. Giving and Receiving Compliments (3.47 = important)

4. Describing Hospitality Facilities (3.45 = important)

5. Asking For and Giving Opinions (3.44 = important)

6. Asking for Permission (3.43 = important)

7. Asking for Repeats (3.38 = important)

8. Offering Help and Advice (3.42 = important)

9. Problems and Complaints (3.42 =important)

10. Describing Functions and Purposes (3.41 = important) 
TABLE 11: Perceptions on the most Preferred Topics to Learn in Hospitality.

\begin{tabular}{|c|c|}
\hline No. & Suggested Topics \\
\hline 1 & Greeting and Receiving Guests \\
\hline 2 & Using the Telephone \\
\hline 3 & Giving and Receiving Compliments \\
\hline 4 & Describing Hospitality Facilities \\
\hline 5 & Asking For and Giving Opinions \\
\hline 6 & Asking for Permission \\
\hline 7 & Asking for Repeats \\
\hline 8 & Offering Help and Advice \\
\hline 9 & Problems and Complaints \\
\hline 10 & Describing Functions and Purposes \\
\hline 11 & Dealing with Guests Requests \\
\hline 12 & Giving Instructions \\
\hline 13 & Bill Settlement \\
\hline 14 & Making Comparisons \\
\hline 15 & Shopping at the Hospitality \\
\hline 16 & $\begin{array}{l}\text { Suggested topic: Responding to } \\
\text { Guest's Complain }\end{array}$ \\
\hline 17 & Describing Jobs \\
\hline \multirow[t]{3}{*}{18} & Days and Time \\
\hline & $0-1.50=$ not important \\
\hline & $1.50-2.50=$ less important \\
\hline
\end{tabular}

\begin{tabular}{|c|c|c|c|}
\hline \multicolumn{3}{|c|}{ Respondent } & Average \\
\hline Student & Teacher & Employees & \\
\hline 3.23 & 4.00 & 3.43 & 3.55 \\
\hline 2.77 & 4.00 & 3.71 & 3.49 \\
\hline 2.83 & 4.00 & 3.57 & 3.47 \\
\hline 2.91 & 4.00 & 3.43 & 3.45 \\
\hline 2.74 & 4.00 & 3.57 & 3.44 \\
\hline 2.86 & 4.00 & 3.43 & 3.43 \\
\hline 2.57 & 4.00 & 3.57 & 3.38 \\
\hline 2.83 & 4.00 & 3.43 & 3.42 \\
\hline 2.69 & 4.00 & 3.57 & 3.42 \\
\hline 2.66 & 4.00 & 3.57 & 3.41 \\
\hline 2.51 & 4.00 & 3.57 & 3.36 \\
\hline 2.66 & 4.00 & 3.43 & 3.36 \\
\hline 2.38 & 4.00 & 3.71 & 3.36 \\
\hline 2.63 & 4.00 & 3.43 & 3.35 \\
\hline 2.46 & 4.00 & 3.43 & 3.30 \\
\hline 3.23 & 4.00 & 2.29 & 3.17 \\
\hline 2.48 & 3.50 & 2.57 & 2.85 \\
\hline 2.71 & 3.00 & 2.57 & 2.76 \\
\hline & $2.51-3.50=$ important & \\
\hline & $3.51-4.00=$ very important & \\
\hline & & & \\
\hline & & & \\
\hline & & & \\
\hline & & & \\
\hline & & & \\
\hline & & & \\
\hline
\end{tabular}

Source: Primary data processing

11. Dealing with Guests Requests (3.36 = important)

12. Giving Instructions (3.36 = important)

13. Bill Settlement (3.36 = important)

14. Making Comparisons (3.35 = important)

15. Shopping at the Hospitality (3.35 = important)

16. Responding to Guest's Complain (3.17 = important)

17. Describing Jobs $(2.85=$ important $)$

18. Days and time (2.76 = important)

f. Ranking of participant's Perceptions about Grammar Item to be included in the Syllabus Design 
TABLE 12: Perceptions on Grammar Items for Syllabus Design.

\begin{tabular}{|c|c|c|c|c|c|}
\hline \multirow[t]{2}{*}{ No. } & \multirow[t]{2}{*}{ Suggested Grammar Items } & \multicolumn{3}{|c|}{ Respondent } & \multirow[t]{2}{*}{ Average } \\
\hline & & Student & Teacher & Employees & \\
\hline 1 & Past tense & 3.00 & 4.00 & 3.71 & 3.57 \\
\hline 2 & w-h question & 2.94 & 4.00 & 3.71 & 3.55 \\
\hline 3 & Present tense & 3.11 & 4.00 & 3.43 & 3.51 \\
\hline 4 & Subject Pronoun & 3.40 & 3.00 & 3.28 & 3.23 \\
\hline 5 & Subject verb agreement & 3.09 & 3.50 & 3.00 & 3.20 \\
\hline 6 & Greeting & 3.03 & 3.50 & 3.00 & 3.18 \\
\hline 7 & Phrase & 2.60 & 3.00 & 3.57 & 3.06 \\
\hline 8 & Number & 3.00 & 3.00 & 3.14 & 3.05 \\
\hline 9 & Degree of comparison & 2.40 & 4.00 & 2.71 & 3.04 \\
\hline 10 & Future tense & 2.71 & 2.50 & 3.86 & 3.02 \\
\hline 11 & Pronoun & 2.71 & 3.00 & 3.14 & 2.95 \\
\hline 12 & Conditional sentence & 2.91 & 3.00 & 2.86 & 2.92 \\
\hline 13 & Demonstrative & 2.60 & 3.00 & 3.00 & 2.87 \\
\hline 14 & Some/any, much/many, a little/a few & 2.89 & 3.00 & 2.00 & 2.63 \\
\hline 15 & Superlative & 2.29 & 3.00 & 2.57 & 2.62 \\
\hline 16 & Yes-no question & 2.97 & 1.00 & 3.71 & 2.56 \\
\hline 17 & Quantity & 2.54 & 3.00 & 1.86 & 2.47 \\
\hline 18 & Determiner & 2.54 & 2.50 & 2.00 & 2.35 \\
\hline 19 & Countable and uncountable & 2.57 & 2.00 & 2.43 & 2.33 \\
\hline 20 & Affixes & 2.14 & 2.00 & 2.43 & 2.19 \\
\hline 21 & Inviting & 2.20 & 3.50 & 2.86 & 2.85 \\
\hline \multirow[t]{3}{*}{22} & Suggested: Question Tag & 0 & 2.5 & 1.86 & 2.18 \\
\hline & \multicolumn{2}{|l|}{$0-1.50=$ not important } & \multicolumn{3}{|c|}{$2.51-3.50=$ important } \\
\hline & \multicolumn{2}{|l|}{$1.50-2.50=$ less important } & \multicolumn{3}{|c|}{$3.51-4.00=$ very important } \\
\hline
\end{tabular}

Based on the data table 15, showed that there were sixteen grammar items that to be included in the syllabus design. The items selected have average score range from 2.85 to 3.57 . The grammar items could then be listed into order according to level of importance as follows:

1. Past tense $(3.57=$ very important $)$

2. $\mathrm{w}$-h question $(3.55=$ very important $)$

3. Present tense $(3.51=$ very important $)$

4. Subject Pronoun (3.23 = important)

5. Subject verb agreement $(3.20=$ important $)$

6. Greeting $(3.18=$ important $)$

7. Phrase $(3.06=$ important $)$

8. Number (3.05 = important) 
9. Degree of comparison (3.04 = important)

10. Future tense (3.02 = important)

11. Pronoun $(2.95=$ important $)$

12. Conditional sentence $(2.93=$ important $)$

13. Demonstrative $(2.87=$ important $)$

14. Some/any, much/many, a little/a few $(2.63=$ important $)$

15. Superlative $(2.62=$ important $)$

16. Yes-no question (2.18 = important)

\section{Description of Students' Learning Problem}

\section{a. Ranking of participant's Perceptions about Problem in every single skill}

According to table 16, it showed that students faced all problems in all skills of English, table above indicating important scale were available. It clearly showed there were six problems that faced by the students in the listening skill. Then, there were four obstacles identified in speaking skill. Also, there were four difficulties that faced by the students in reading. Hence, identifying three problems in writing, those were selected have average score range from 2.65 to 3.22 . The problems could then be listed into order according to level of importance as follows:

1. The first is listening problems. The obstacles faced such as audio should be repeated several times (3.22), only understand with a slowly speak (3.10), difficulties in listening the long speaks (3.06), every single word should be translated one by one (3.02), lack of some vocabularies (2.98), and only understand the common words (2.78);

2. The second is speaking problems. The difficulties associated with afraid to make an error (3.06), lack of vocabulary and Grammar (3,02), lack of pronunciation (2.82), and insufficient knowledge of the topic (2.81);

3. The third is reading problems. Those were every single word should be translated one by one (3.01), lack of vocabulary and grammar (2.75), the content of materials are not suitable with Hospitality term (2.73), and lack of reading Motivation (2.65);

4. The fourth is writing problems. Those difficulties were like lack of vocabulary and grammar (2.85), insufficient knowledge of writing skill (2.67), and miss-spelling (2.67). 
TABLE 13: Perceptions on their Problems of Specific Skill.

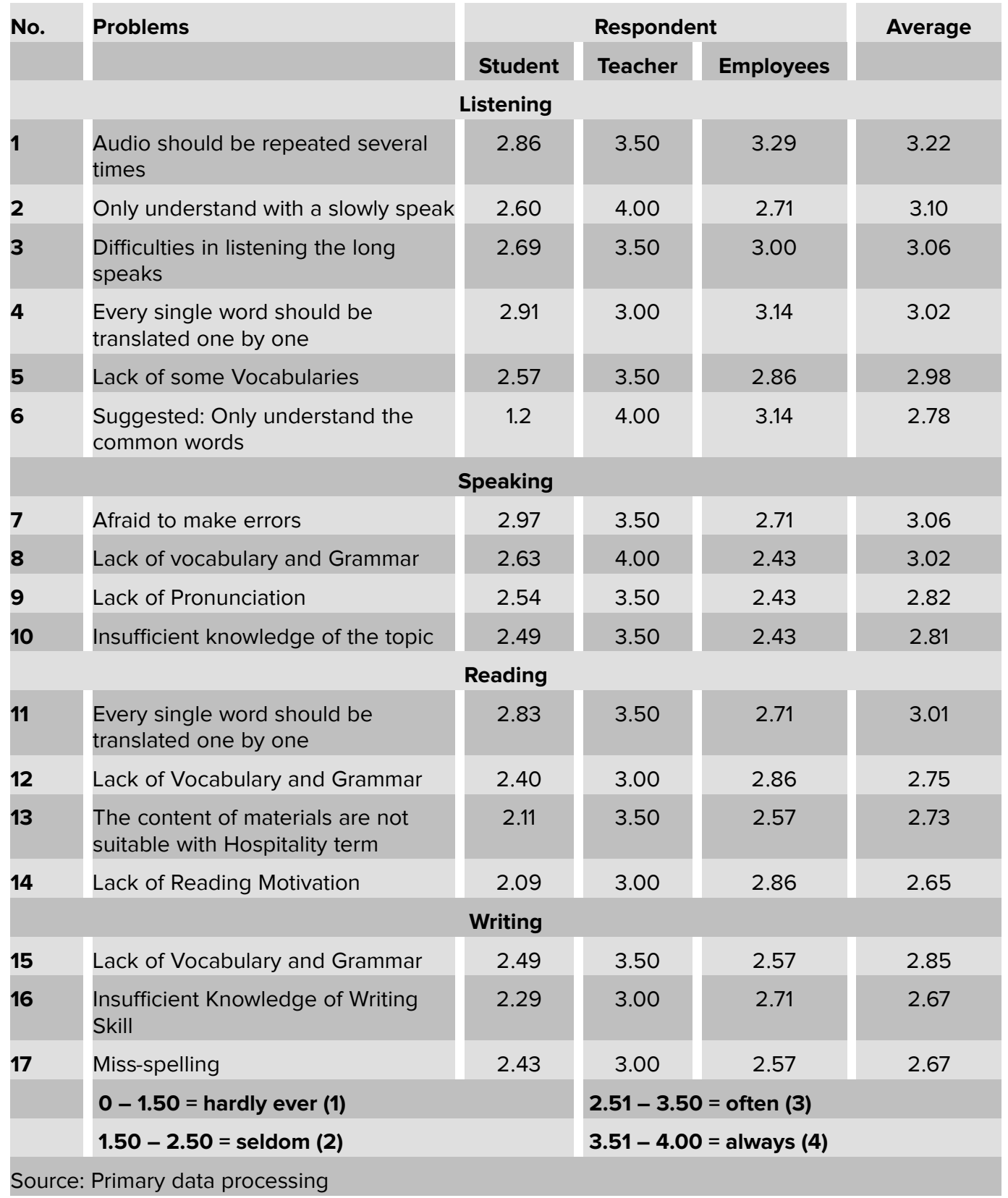

The learning problems faced by the students were in the 'often' level of frequency because all the problem average scores range from 2.65 to 3.22 which mean 'often' occurred. All these supported that importance for teachers, curriculum designers, and also researchers who had intention to help students reduced the effects of those obstacles and to maximize their learning in English by selecting the most appropriate approaches, methods, and strategies in teaching as the possible solutions to overcome the problems. 


\section{b. Ranking of participant's Perceptions about Learning Preferences in Reading} Skill

TABLE 14: Perception on Learning Preferences in Reading Skill.

\begin{tabular}{|c|c|c|c|c|c|}
\hline \multirow[t]{2}{*}{ No. } & \multirow{2}{*}{$\begin{array}{l}\text { Reading Learning } \\
\text { Preferences }\end{array}$} & \multicolumn{3}{|c|}{ Respondent } & \multirow[t]{2}{*}{ Average } \\
\hline & & Student & Teacher & Employees & \\
\hline 1 & $\begin{array}{l}\text { Reading } \\
\text { Continuously }\end{array}$ & 3.00 & 3.00 & 3.14 & 3.05 \\
\hline \multirow[t]{3}{*}{2} & $\begin{array}{l}\text { Skimming and } \\
\text { Scanning }\end{array}$ & 2.86 & 2.50 & 3.00 & 2.79 \\
\hline & \multicolumn{2}{|c|}{$0-1.50=$ not important } & \multicolumn{3}{|c|}{$2.51-3.50=$ important } \\
\hline & \multicolumn{2}{|c|}{$1.50-2.50=$ less important } & \multicolumn{3}{|c|}{$3.51-4.00=$ very important } \\
\hline
\end{tabular}

As is shown in the table above, we can conclude that there were two ways of reading learning preference; reading continuously (3.05), skimming and scanning (2.79) meaning that those are in 'important' level.

\section{c. Ranking of participant's Perceptions about Learning Preferences in Speaking Skill}

TABLE 15: Perception on Learning Preferences in Speaking Skill.

\begin{tabular}{|c|c|c|c|c|c|}
\hline \multirow[t]{2}{*}{ No. } & \multirow{2}{*}{$\begin{array}{l}\text { Speaking Learning } \\
\text { Preferences }\end{array}$} & \multicolumn{3}{|c|}{ Respondent } & \multirow[t]{2}{*}{ Average } \\
\hline & & Student & Teacher & Employees & \\
\hline 1 & Speaking Simulation & 2.94 & 3.00 & 3.14 & 3.03 \\
\hline 2 & Interviewing & 2.91 & 1.50 & 2.43 & 2.28 \\
\hline \multirow[t]{3}{*}{3} & Reporting & 2.46 & 1.50 & 2.14 & 2.03 \\
\hline & \multicolumn{2}{|c|}{$0-1.50=$ not important } & \multicolumn{3}{|c|}{$2.51-3.50=$ important } \\
\hline & \multicolumn{2}{|c|}{$1.50-2.50=$ less important } & \multicolumn{3}{|c|}{$3.51-4.00=$ very important } \\
\hline
\end{tabular}

The striking point about these results is that there was only one preference in speaking skill that reached off in mean scores. The above data illustrate, from the students' point of view, learning preferences through reporting (2.03), through speaking simulation (3.03) and interviewing (2.28). It could then be listed into order according to level of importance as follows:

1. Speaking simulation $(3.03=$ important $)$

2. Interviewing (2.28 = less important) 
3. Reporting ( $2.03=$ less important)

\section{d. Ranking of participant's Perceptions about Learning Preferences in Listening Skill}

This section presents the preference faced in listening skill where we can see that there were completing the test from audio recording (2.88) as the first rank, listening while writing (2.53) as the second rank, watching video (2.53) as the third rank, and the last imitating teacher dictation (2.45). The fact is proven by the average scores attainment in which average score from 2.53 to 2.88 were in 'important' level, meaning that there were there available suggested listening learning preferences should be employed by the students, those were (1) completing the test from audio, (2) listening while writing, and (watching video).

The results were illustrated in table below:

TABLE 16: Perception on Learning Preference in Listening Skill.

\begin{tabular}{|c|c|c|c|c|c|}
\hline \multirow[t]{2}{*}{ No. } & \multirow{2}{*}{$\begin{array}{l}\text { Listening Learning } \\
\text { Preferences }\end{array}$} & \multicolumn{3}{|c|}{ Respondent } & \multirow[t]{2}{*}{ Average } \\
\hline & & Student & Teacher & Employees & \\
\hline 1 & $\begin{array}{l}\text { Completing the test } \\
\text { from Audio Recording }\end{array}$ & 2.51 & 3.00 & 3.14 & 2.88 \\
\hline 2 & Listening while Writing & 3.03 & 2.00 & 2.57 & 2.53 \\
\hline 3 & Watching Video & 2.29 & 3.00 & 2.29 & 2.53 \\
\hline \multirow[t]{3}{*}{4} & $\begin{array}{l}\text { Imitating teacher } \\
\text { dictation }\end{array}$ & 2.43 & 2.50 & 2.43 & 2.45 \\
\hline & \multicolumn{2}{|l|}{$0-1.50=$ not important } & \multicolumn{3}{|c|}{$2.51-3.50=$ important } \\
\hline & \multicolumn{2}{|c|}{$1.50-2.50=$ less important } & \multicolumn{3}{|c|}{$3.51-4.00=$ very important } \\
\hline
\end{tabular}

Hence, we can now take a look at by the priority scale to clearly describe what ways of learning listening should be employed:

1. Completing the test from Audio Recording ( $2.88=$ important)

2. Listening while Writing $(2.53=$ important $)$

3. Watching Video $(2.53=$ important $)$

\section{e. Ranking of participant's Perceptions about Learning Preferences in Writing Skill}

The above table shows that there were three possible ways of learning writing which given to the students so that they provide their perceptions on which way among the three most preferred ways for the students to learn writing. The fact is proven by the 
TABLE 17: Perception on Learning Preferences in Writing Skill.

\begin{tabular}{|c|c|c|c|c|c|}
\hline \multirow[t]{2}{*}{ No. } & \multirow{2}{*}{$\begin{array}{l}\text { Writing Learning } \\
\text { Preferences }\end{array}$} & \multicolumn{3}{|c|}{ Respondent } & \multirow[t]{2}{*}{ Average } \\
\hline & & Student & Teacher & Employees & \\
\hline 1 & Developing ideas & 3.17 & 3.00 & 3.29 & 3.15 \\
\hline 2 & Arranging text & 2.74 & 3.00 & 3.29 & 3.01 \\
\hline 3 & $\begin{array}{l}\text { Writing Letter in } \\
\text { Formal and informally }\end{array}$ & 2.77 & 2.00 & 3.00 & 2.59 \\
\hline \multirow[t]{3}{*}{4} & Writing Reports & 2.83 & 2.00 & 2.14 & 2.32 \\
\hline & \multicolumn{2}{|c|}{$0-1.50=$ not important } & \multicolumn{3}{|c|}{$2.51-3.50=$ important } \\
\hline & \multicolumn{2}{|c|}{$1.50-2.50=$ less important } & \multicolumn{3}{|c|}{$3.51-4.00=$ very important } \\
\hline
\end{tabular}

average scores attainment in which average score from 2.59 to 3.15 were in 'important' level, meaning that there were there available suggested writing learning preferences should be employed by the students, those were developing ideas (3.15), arranging text (3.01), writing Letter in Formal and informally (2.59). According to the data results indicates that the respondents assumed the most preferred way of learning English is "Developing ideas", this learning style achieves the highest average score among others that mean was 3.15 which means in 'important' level.

\section{f. Ranking of participant's Perceptions about Student's Teaching Style}

TABLE 18: Perception on Student's Teaching Style.

\begin{tabular}{|c|c|c|c|c|c|}
\hline \multirow[t]{2}{*}{ No. } & \multirow[t]{2}{*}{ Learning Style } & \multicolumn{3}{|c|}{ Respondent } & \multirow[t]{2}{*}{ Average } \\
\hline & & Student & Teacher & Employees & \\
\hline 1 & Talk to Friends & 2.74 & 4.00 & 3.71 & 3.48 \\
\hline 2 & Taking in Pairs & 3.11 & 3.50 & 3.71 & 3.44 \\
\hline 3 & Games & 2.60 & 4.00 & 3.43 & 3.34 \\
\hline 4 & Doing Tasks & 3.26 & 3.00 & 3.29 & 3.18 \\
\hline 5 & Studying alone & 2.60 & 2.50 & 3.86 & 2.99 \\
\hline 6 & Large Group & 2.51 & 3.00 & 3.43 & 2.98 \\
\hline 7 & Film and Video & 2.54 & 3.00 & 3.14 & 2.89 \\
\hline 8 & Small Group & 2.54 & 2.50 & 3.57 & 2.87 \\
\hline 9 & Pictures & 2.46 & 3.00 & 2.57 & 2.68 \\
\hline \multirow[t]{3}{*}{10} & Role Play & 2.26 & 3.50 & 1.86 & 2.54 \\
\hline & \multicolumn{2}{|c|}{$0-1.50=$ not important } & \multicolumn{3}{|c|}{$2.51-3.50=$ important } \\
\hline & \multicolumn{2}{|c|}{$1.50-2.50=$ less important } & \multicolumn{3}{|c|}{$3.51-4.00=$ very important } \\
\hline
\end{tabular}

Among respondents responses show that they prefer 'talk to Friends in English' as the most selected learning style category. This category achieves the highest average score 
among the others that was 3.48 which means 'important' level. The other categories could then be listed into order according to level of importance as follows:

1. Learning English by talking to Friends (3.84 = very important)

2. Learning English by talking in Pairs (3.48 = important)

3. Learning English by games (3.34 = important)

4. Learning English by doing tasks (3.18 = important)

5. Learning English by studying alone (2.99) = important)

6. Learning English in large group (2.98 = important)

7. Learning English by film and video $(2.89=$ important $)$

8. Learning English by in small group (2.87 = important)

9. Learning English by pictures (2.68 = important)

10. Learning English by role play $(2.54=$ important $)$

In short, even though there were some differences on the responses from among students, teachers, and graduates, conclusion stated that all suggested learning style categories were available to be applied and could still be derived from the results; that some language activities stated in the questionnaires involves directly with students of Vocational School 2 Pangkep.

Therefore, learning styles for the hospitality is different from other English programs (Barron \& Arcodia, 2002; Dale \& McCarthy, 2006). According to Cassidy (2004), a learning style integrates people's affective, cognitive, and psychological traits. Conner (2007) believes that learning styles are mainly related to processes, learners' perception, organization, and present information developed during the past decades. In 1987, Neil Fleming developed VARK, and its seminal publication appeared in 1992. Fleming showed that people have preferred sensory routes for learning based on learner type.

He classified them as the four learning styles of the VARK model:

1. Visual/seeing

2. Aural/listening

3. Read/Write

4. Kinesthetic/experiencing 
Moreover, Honey and Mumford (1995) investigated four major learning styles in which learners had a preferred learning style that determines how they enjoy learning the theorist, pragmatist, activist, and reflector. Studies have indicated that learners are more attracted to practical activities rather than theory and reflection. As a result, educators are required to instruct and educate the learners through different teaching styles to increase their learning preference in certain programs (Barron \& Arcodia, 2002; Lashley, 1999; Lashley \& Barron, 2006; Dale \& McCarthy, 2006, Bahar, A. K. 2013).

\section{Description of Reviewing Students' Need Inventory and determining aims and objectives of the course}

The analysis results of the students' linguistics and learning needs have enriched the understanding of overall needs that are required to design syllabus and material development for the Hospitality Students at Vocational School 2 Pangkep. The result of the analysis from the students, the graduates, as well as the teachers' perceptions found out various needs categories to be taken into account when designing syllabus and developing instructional materials of Hospitality department as follows:

a. Reviewing Needs Inventory from the Linguistics Needs

Identifying linguistic needs is carried out by analyzing the students' learning ability and learning priority. The result of the analysis are used for prioritizing the components of four skills and selecting appropriate teaching materials which are required to design the syllabus and materials in Hospitality department, especially for ten grade students.

\subsection{Determining the aims and objectives of the course}

Richard (2001: 120) suggests that aims have four main purposes:

1. To provide a reason for the program

2. To provide guidelines for teachers and learners

3. To provide a focus for learning

4. To describe important and realizable change in learning (or in students)

Objectives help planning the course and enable evaluators to judge the success or failure of a program. Richards (2001: 123) suggests that objectives generally have the following characteristics:

1. They describe what the aims seeks to achieve in terms of smaller units of learning 


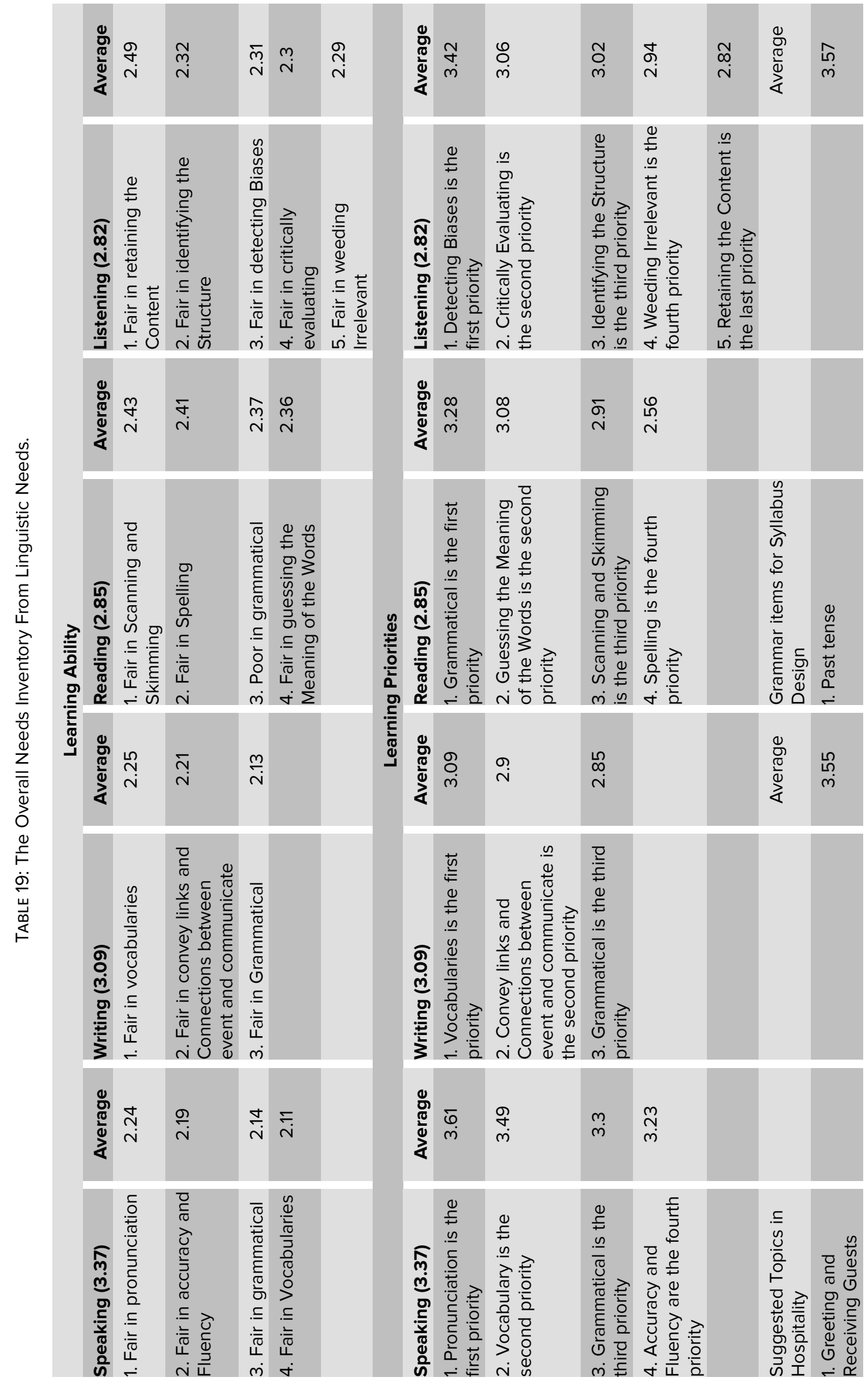




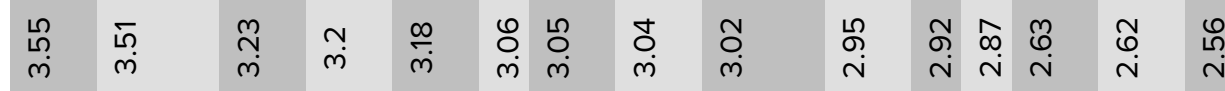
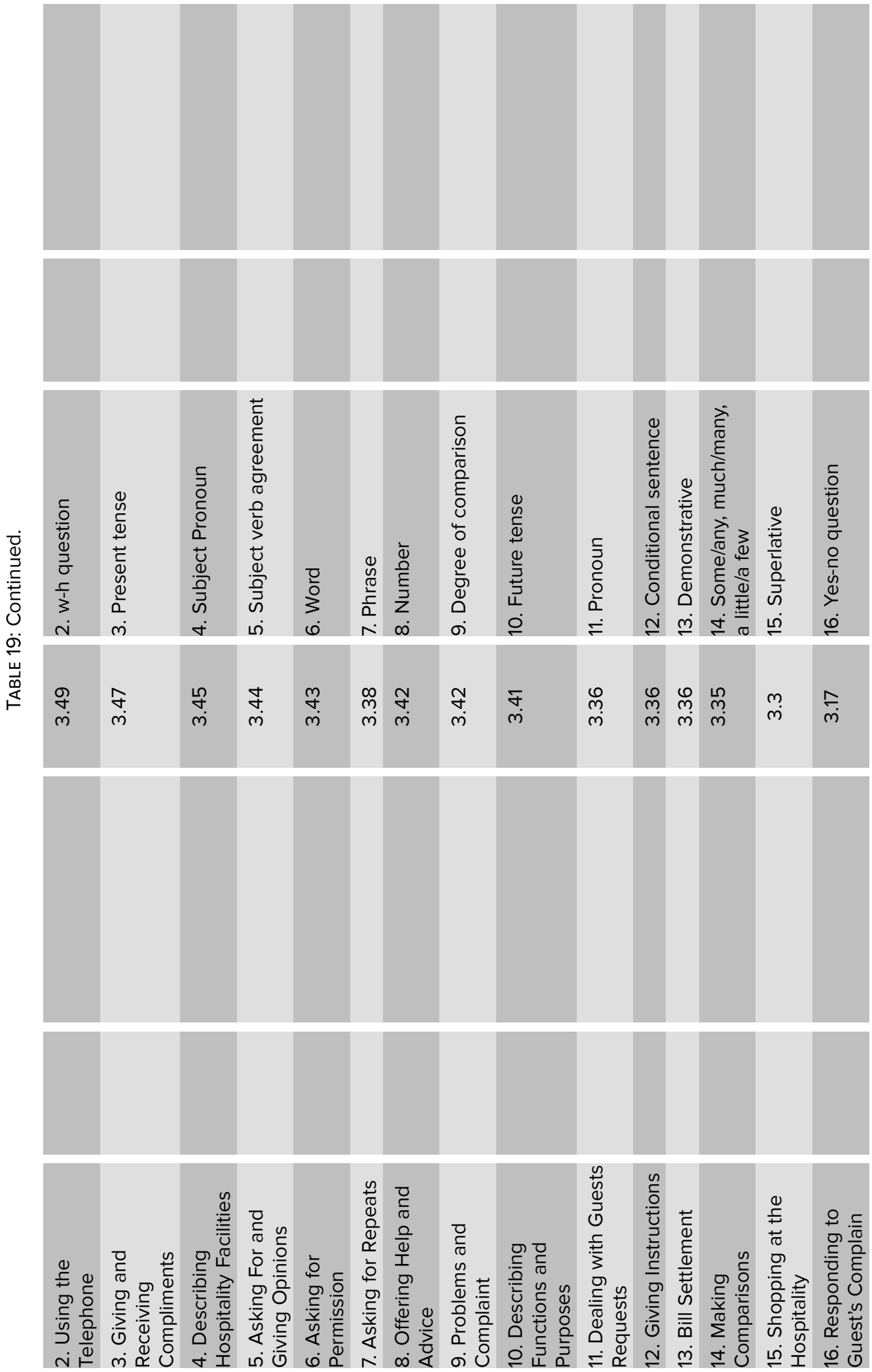


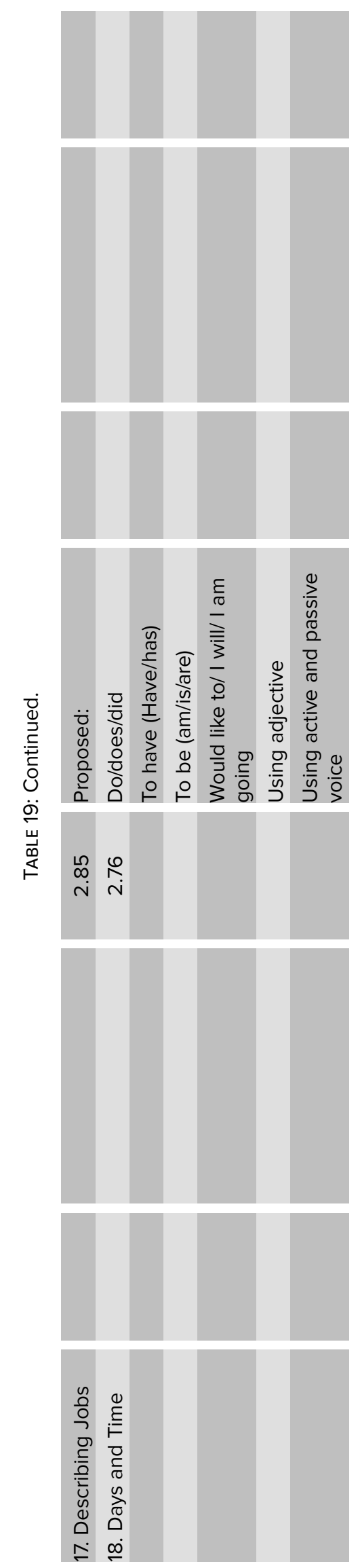


2. They provide the basis for the organization of teaching activities

3. They describe learning in terms of observable behavior or performance

4. They facilitate planning: once objectives have been agreed on, course planning, materials preparation, textbook selection, and related processes can begin

5. They provide measurable outcomes and thus provide accountability given a set of objectives, the success or failure of a program to teach the objective can be measured.

6. They are prescriptive: they describe how planning should proceed and do away with subjective interpretations and personal opinions.

Besides, Richards (2001: 123) also describe that statements of objective possess the following characteristics:

1. Objectives describe a learning outcome

2. Objective should be consistent with the curriculum aim

3. Objective should be precise and feasible

The result of the data gathered through questionnaires and interviews has been analyzed and put in the table to be clarified qualitatively. The result of the analysis has shown the need analysis conducted specifically to design syllabus of Hospitality department especially for tenth grade students in integrating to the todays curricula. In principle, this material is adjusted to meet graduate competency standards and content standards in the national curriculum:

1. Determination of the graduate competency approach is preceded by identifying what is to be formed, built, and empowered in students as a guarantee that they will achieve after completing their education in a particular education unit. Thus, this material design is designed by integrating the Communicative approach as a strengthening of the scientific approach; Observing (observing), asking (questioning), gathering information (collecting information), associating (associating), and communicating (communicating) where the communicative approach is very necessary for the level of vocational education, especially for Hospitality.

2. Based on Law Number 20 of 2013 , the learning process is fully directed towards Graduates' Competency Standards (SKL) in the development of three domains, including grouped in three achievement domains: affective domain (attitude), cognitive domain (knowledge), and psychomotor domain (skills). The three domains 
of competency have different acquisition trajectories, attitudes obtained through activities' accepting, exercising, appreciating, living, and practicing ', Knowledge gained through' remembering, understanding, applying, analyzing, evaluating, creating 'Skills acquired through activity' observing, asking, trying, reasoning, presenting and creating.

3. Furthermore, Core Competencies are formulated using the following notation:

(a) Core Competence 1 (KI-1) for core competencies in spiritual attitudes;

(b) Core Competence 2 (KI-2) for core competencies in social attitudes;

(c) Core Competence 3 (KI-3) for knowledge competence, and

(d) Core Competence $4(\mathrm{KI}-4)$ for core competency skills

In its implementation, direct learning mode and indirect instruction are used where direct learning is learning that develops knowledge, thinking skills and skills contained in $\mathrm{KI}-3$ and $\mathrm{KI}-4$, while indirect learning is learning that occurs during the learning process that is conditioned includes the development of values and attitudes that are contained in $\mathrm{KI}-1$ and $\mathrm{KI}-2$.

4. In addition, in the learning process, the teacher can carry out formative assessment activities to monitor student learning progress, find obstacles or evaluate the steps of division. The affirmation is stated in Government Regulation Number 32 of 2013 concerning changes to Government Regulation Number 19 of 2005 concerning National Education Standards. Assessment of learning outcomes by educators has a role, among others, to help students find out about learning outcomes (learning outcomes). That way, educators and students can obtain information about the weaknesses and strengths of learning and learning so that it is easy to take steps to correct or reflect on what has been learned.

Referring to the theoretical point of view about aims and objectives based on the needs inventory from the respondents' perceptions of Hospitality Department at Vocational high School 2 Pangkep in integrating competency standards and content standards in the national curriculum, this research formulates the course' aims and objectives.

TABLE 20: The Overall Needs Inventory From Learning Needs.

\begin{tabular}{llllll}
\multicolumn{5}{c}{ The Learning Problems } \\
$\begin{array}{l}\text { Speaking } \\
\text { (3.37) }\end{array}$ & Average Writing & Average & Reading & Average Listening & Average \\
(3.09) & & (2.85) & (2.82) &
\end{tabular}




\begin{tabular}{|c|c|c|c|c|c|c|c|}
\hline $\begin{array}{l}\text { 1. Afraid to } \\
\text { make errors }\end{array}$ & 3.06 & $\begin{array}{l}\text { 1. Lack of } \\
\text { Vocabulary } \\
\text { and Grammar }\end{array}$ & 2.85 & $\begin{array}{l}\text { 1. Every } \\
\text { single word } \\
\text { should be } \\
\text { translated } \\
\text { one by one }\end{array}$ & 3.01 & $\begin{array}{l}\text { 1. Audio } \\
\text { should be } \\
\text { repeated } \\
\text { several times }\end{array}$ & 3.22 \\
\hline $\begin{array}{l}\text { 2. Lack of } \\
\text { vocabulary } \\
\text { and Grammar }\end{array}$ & 3.02 & $\begin{array}{l}\text { 2. Insufficient } \\
\text { Knowledge } \\
\text { of Writing } \\
\text { Skill }\end{array}$ & 2.67 & $\begin{array}{l}\text { 2. Lack of } \\
\text { Vocabulary } \\
\text { and Grammar }\end{array}$ & 2.75 & $\begin{array}{l}\text { 2. Only } \\
\text { understand } \\
\text { with a slowly } \\
\text { speak }\end{array}$ & 3.1 \\
\hline $\begin{array}{l}\text { 3. Lack of } \\
\text { Pronunciation }\end{array}$ & 2.82 & $\begin{array}{l}3 . \\
\text { Miss-spelling }\end{array}$ & 2.67 & $\begin{array}{l}\text { 3. The } \\
\text { content of } \\
\text { materials are } \\
\text { not suitable } \\
\text { with } \\
\text { Hospitality } \\
\text { term }\end{array}$ & 2.73 & $\begin{array}{l}\text { 3. Difficulties } \\
\text { in listening } \\
\text { the long } \\
\text { speaks }\end{array}$ & 3.06 \\
\hline \multirow[t]{3}{*}{$\begin{array}{l}\text { 4. Insufficient } \\
\text { knowledge of } \\
\text { the topic }\end{array}$} & \multirow{3}{*}{\multicolumn{2}{|c|}{2.81}} & & $\begin{array}{l}\text { 4. Lack of } \\
\text { Reading } \\
\text { Motivation }\end{array}$ & 2.65 & $\begin{array}{l}\text { 4. Every } \\
\text { single word } \\
\text { should be } \\
\text { translated } \\
\text { one by one }\end{array}$ & 3.02 \\
\hline & & & & & & $\begin{array}{l}\text { 5. Lack of } \\
\text { some } \\
\text { Vocabularies }\end{array}$ & 2.98 \\
\hline & & & & & & $\begin{array}{l}\text { 6. Only } \\
\text { understand } \\
\text { the common } \\
\text { words }\end{array}$ & 2.78 \\
\hline \multicolumn{8}{|c|}{ The Learning Attitude } \\
\hline \multicolumn{8}{|c|}{ Learning Preferences } \\
\hline $\begin{array}{l}\text { Speaking } \\
\text { (3.37) }\end{array}$ & Average & $\begin{array}{l}\text { Writing } \\
\text { (3.09) }\end{array}$ & Average & $\begin{array}{l}\text { Reading } \\
(2.85)\end{array}$ & Average & $\begin{array}{l}\text { Listening } \\
(2.82)\end{array}$ & Average \\
\hline $\begin{array}{l}\text { 1. Speaking } \\
\text { Simulation }\end{array}$ & 3.03 & $\begin{array}{l}\text { 1. Developing } \\
\text { ideas }\end{array}$ & 3.13 & $\begin{array}{l}\text { 1. Reading } \\
\text { Continuously }\end{array}$ & 3.05 & $\begin{array}{l}\text { 1. Completing } \\
\text { the test from } \\
\text { Audio } \\
\text { Recording }\end{array}$ & 2.88 \\
\hline $\begin{array}{l}2 . \\
\text { Interviewing }\end{array}$ & 2.28 & $\begin{array}{l}\text { 2. Arranging } \\
\text { text }\end{array}$ & 3.01 & $\begin{array}{l}\text { 2. Skimming } \\
\text { and Scanning }\end{array}$ & 2.79 & $\begin{array}{l}\text { 2. Listening } \\
\text { while Writing }\end{array}$ & 2.53 \\
\hline \multirow[t]{2}{*}{ 3. Reporting } & 2.03 & $\begin{array}{l}\text { 3. Writing } \\
\text { Letter in } \\
\text { Formal and } \\
\text { informally }\end{array}$ & 2.59 & & & $\begin{array}{l}\text { 3. Watching } \\
\text { Video }\end{array}$ & 2.53 \\
\hline & & $\begin{array}{l}\text { 4. Writing } \\
\text { Reports }\end{array}$ & & & & $\begin{array}{l}\text { 4. Imitating } \\
\text { teacher } \\
\text { dictation }\end{array}$ & 2.45 \\
\hline \multicolumn{6}{|l|}{ Learning Style } & & Average \\
\hline \multicolumn{5}{|c|}{ 1. Learning English by talking to Friends } & & & 3.48 \\
\hline \multicolumn{5}{|c|}{ 2. Learning English by taking in Pairs } & & & 3.44 \\
\hline \multicolumn{5}{|c|}{ 3. Learning English by games } & & & 3.34 \\
\hline \multicolumn{5}{|c|}{ 4. Learning English by doing tasks } & & & 3.18 \\
\hline \multicolumn{5}{|c|}{ 5. Learning English by studying alone } & & & 2.99 \\
\hline \multicolumn{5}{|c|}{ 6. Learning English in large group } & & & 2.98 \\
\hline
\end{tabular}




\section{Aims}

1. Live and practice the teachings of the religion he/she adheres to.

2. Live and practice honest behavior, discipline, responsibility, caring (mutual cooperation, cooperation, tolerance, peace), courtesy, responsiveness and pro-active and showing attitude as part of the solution to various problems in interacting effectively with the social and natural environment and in placing themselves as a reflection of the nation in world relations.

3. Generate ideas about topic along the way, then having students explain their thinking into general guidelines out loud and analyzing procedural knowledge to the specific field of study according to his talents and interests to solve problems.

4. Practice task related to the development of what is learned in school independently, and being able to use it according to scientific rules of Hospitality.

\section{Objectives}

1.1 Being grateful for the opportunity to learn English as the medium of instruction for international communication is realized in the spirit on learning.

2.1 Demonstrate polite and caring behavior in carrying out interpersonal communication with teachers and friends.

2.2 Demonstrate honest, disciplined, confident, and responsible behavior in carrying out transactional communication with teachers and friends.

2.3 Demonstrate responsibility, caring, cooperation and peace-loving behavior in carrying out functional communication.

3.1 Students will analyze how to greet and receive the guests

3.1.1 Students will analyze how to chit-chat in receiving the guests and identify appropriate topics to talk about.

3.1.2 Students will analyze various expressions for farewells.

3.2 Students will analyze how to describe using telephone 
3.3 Students will analyze how to give and receive compliment

3.4 Students will analyze how to describe hospitality facilities

3.5 Students will analyze how to ask for and giving options

3.6 Students will analyze how to ask for permission

3.7 Students will analyze how to ask for repeats

3.8 Students will analyze how to offer help and advice

3.9 Students will analyze how to answer problems and complaint

3.10 Students will analyze how to describe function and purpose

3.11 Students will I analyze how to respond the guests' requests

3.12 Students will analyze how to give instructions.

3.13 Students will analyze how to describe bill settlement

3.14 Students will analyze how to make comparisons

3.15 Students will analyze how to describe steps of shopping at the hotel

3.16 Students will analyze how to respond guests' complain

3.17 Students will analyze how to describe job

3.18 Students will analyze how to describe days and time

4.1 Students are expected to be able to greet and receive the guests

4.2 Students are expected to be able to chit-chat in receiving the guests and identify appropriate topics to talk about.

4.2.1 Students are expected to be able to identify various expressions for farewells.

4.3 Students are expected to be able to describe using telephone

4.4 Students are expected to be able to give and receive compliment

4.5 Students are expected to be able to describe hospitality facilities

4.6 Students are expected to be able to ask for and giving options

4.7 Students are expected to be able to ask for permission

4.8 Students are expected to be able to ask for repeats

4.9 Students are expected to be able to offer help and advice

4.10 Students are expected to be able to answer problems and complaint

4.11 Students are expected to be able to describe function and purpose

4.12 Students are expected to be able to respond the guests' requests

4.13 Students are expected to be able to give instructions.

4.14 Students are expected to be able to describe bill settlement

4.15 Students are expected to be able to make comparisons 
4.16 Students are expected to be able to describe steps of shopping at the hotel

4.17 Students are expected to be able to respond guests' complain

4.18 Students are expected to be able to describe job

4.19 Students are expected to be able to describe days and time

\section{Conclusion}

In this study, we have made a considerable effort to do a needs analysis which is regarded essential to develop the syllabus and English teaching materials for vocational purpose for the students at the hospitality department. We revealed three significant findings from doing this needs analysis study namely: The first; three important phases that indicate how to do the needs analysis. The second; useful information on what materials to teach and the methods of how to teach the students of the hospitality department. The information regarding the teaching materials is gained from the needs inventory of the students linguistic needs (learning abilities and priorities). On the other hand, the information concerning the teaching methods is obtained from the needs inventory of the students learning needs (learning problems and learning attitudes). The third; the formulation of aims and objectives required to develop the syllabus and the prototype of ELT Materials for the students of the hospitality department. However, further studies are still needed in two things: Firstly, using these needs inventory to develop syllabus and teaching materials of EVP for the students at the department of hospitality. Secondly, evaluating the effectiveness of the syllabus and the teaching materials in increasing the students' English skills. Hence, it seems reasonable to suggest that the findings should be applied quite reliably in developing well-designed syllabus and teaching materials for the students at the department of Hospitality

\section{References}

[1] Andi, K., \& Arafah, B. (2017). Using needs analysis to develop English teaching materials in initial speaking skills for Indonesian college students of English. The Turkish Online Journal of Design, Art and Communication (TOJDAC), Special Edition, 419-436.

[2] Bahar, A. K. (2013). The Communicative Competence-Based: English Language Teaching. Yogyakarta: TrustMedia.

[3] Bahar, K. (2014). Interactional Speaking a Guide to enchance Natural Communication Skills in English. Yogyakarta: TrustMedia Ethnologue. 
[4] Barron, P., \& Arcodia, C. (2002). Linking Learning Style Preferences and Ethnicity: International Students Studying Hospitality and Tourism Management in Australia. Journal of Hospitality, Leisure, Sport and Tourism Education, 1(2), 1-13. 2 https://doi. org/10.3794/johlste.12.25

[5] Basturkmen, H. (2006). Ideas and Options in English for Specific Purposes.London and New jersey: ESL and Applied Linguistic Professional Series: Eli Hinkel, Edition.

[6] Blue, G.M \& Harun, M. 2003. Hospitality Language as a Professional Skill. English for Spesific Purposes Pergamon Journal. (Online), (http://www.elsevier.com/locate/esp. Accessed 23 Desember 2017)

[7] Cravotta, J. S. (1990). English for Tourism Purposes. A new approach in the field of English for Specific Purposes. Retrieved from http://www.espfortourism.blogspot. my/2012/05/english-for-tourism-purposes.html

[8] Engelmann, S. 1993. The curriculum as the Caused of Failure, Oregon Conference Monograph Journal Vol. 5 1993, University of Oregon United States of America.

[9] Hikmawati (2016). Developing Greeting and Self Introducing Materials dealing with 2013 Curriculum at MTSN Balang-Balang, ETERNAL Volum 3, Number 2. Alauddin University Press.

[10] Hyland, K. (2007). English for Specific Purposes. Springer International Handbooks of Education, 15, 491-402.

[11] Jasso-Aguilar, R. (1999). Sources, methods, and triangulation in needs analysis: A critical perspective in a case study of Waikiki hotel maids. English for Specific Purposes, 18, 27-46.

[12] Kaharuddin, A and Latif, I (2017). The Essential of Discourse Analysis for Teaching English as a Foreign Language, Yogyakarta, Trust Media Publishing.

[13] Kaharuddin, A. (2018). The communicative grammar translation method: a practical method to teach communication skills of English. ETERNAL (English, Teaching, Learning, and Research Journal), 4(2), 232-254.

[14] Kaharuddin, A. (2019). The Power of English: Recognizing and Utilizing the Tremendous Impact of the English Language on the Community. English Language Teaching for EFL Learners, 1(1), 45-51.

[15] Laborda, J. G. (2009). Using web-quests for oral communication in English as a foreign language for tourism studies. Educational Technology \&Society, 12(1), 25870.

[16] Paradowski, M. B. 2002. Need Analysis as The First Step in Syllabus Design, (online). (http://publikacje.ils.uw.edu.pl/publication/view, Retrieved on October 21, 2013) 
[17] Richards, J. C. (2001). Curriculum Development in Language Teaching. New York: Cambridge University Press.

[18] Richards, J. C., Platt, J., \& Wiber, H. (1985). Longman Dictionary Applied Linguistic. London: Longman.

[19] Stapa, S. \& Jais, I. (2005). A survey of writing needs and expectations of hotel management and tourism students. ESP World. 1(9), Vol 4. Retrieved November 13th, 2008 from http://www.esp-world.info/Articles_9/issue_9.htm

[20] Strevens, P. (1988). ESP after twenty years: A re-appraisal. In M. Tickoo (Ed.), ESP: State of the art (pp. 1-13). SEAMEO Regional Language Centre. Cambridge University Press

[21] Strevens, P. (1977). Special purpose language learning: A perspective. Language Teaching and Linguistic Abstracts, 10, 145-163.

[22] Sultana, N. (2011). The effectiveness of the ELT component at the B.Ed. programme in Bangladesh: A critical perspective. Stamford Journal of English, 6, 261-284. DOI: http://dx.doi.org/10.3329/sje.v6i0.13918

[23] Thaine, C. (2010). Teacher Training Essentials: Workshops for professional development. Cambridge: Cambridge University Press.

[24] Tsao, C. H. (2008). English-learning motivation and needs analysis: a case study of technological university students in Taiwan. Paper presented at the Basic Research Conference of Chinese Military Academy on its 84th school anniversary. May 6, 2008. Fongshang, Taiwan.

[25] Tsao, C. H. (2011). English for specific purposes in the EFL context: A survey of student and faculty perceptions. Asian ESP Journal, 7(2), 126-149.

[26] Vlack, S. 2006. English for Spesific Purposes. Part One Ellis \& Johnson (Online Article), (http://www.udveksling.com/ESP2006/, Accessed 3 Maret 2017).

[27] Wello, M. B., \& Dollah, S. (2008). Fundamental Aspect of English for Spesific Purpose. Makassar: Badan Penerbit UNM.

[28] Yassi, A. H. \& Kaharuddin (2018). Syllabus Design for English Language Teaching. Jakarta: Prenada Media 